\title{
1 Identification of essential genes in Caenorhabditis elegans through whole genome sequencing of
}

\section{2 legacy mutant collections}

4 Erica Li-Leger ${ }^{*}$, Richard Feichtinger ${ }^{\dagger \neq}$, Stephane Flibotte $^{\S}$, Heinke Holzkamp $^{\ddagger * *}$, Ralf Schnabel ${ }^{\ddagger}$, 5 Donald G. Moerman*

6

7 *Department of Zoology, University of British Columbia, Vancouver, British Columbia, Canada

8 V6T $1 Z 3$

$9{ }^{\dagger}$ Present Address: Secufy GmbH, CoWorking M1, Anni-Eisler-Lehmannstr. 3, 55122 Mainz,

10 Germany

$11{ }^{\ddagger}$ Department of Developmental Genetics, Institute of Genetics, Technische Universität

12 Braunschweig, 38106, Germany

$13 \S^{\S}$ BC/LSI Bioinformatics Facility, University of British Columbia, Vancouver, British Columbia,

14 Canada.

$15{ }^{* *}$ Present Address: Department of Biochemistry, Ludwig-Maximilians-University Munich, 81377

16 Munich, Germany 
17 Short running title

$18 \quad$ Essential genes in C. elegans

19

20 Key words or phrases

21

- C. elegans

22

- Essential genes

23

- Maternal-effect

24

- Embryogenesis

25

- Fertilization

26

- Legacy mutants

27

- Whole genome sequencing

28

29 Corresponding author:

30 Name: Donald Moerman

31 Office mailing address including street name and number:

32 Department of Zoology

33 Life Sciences Centre

342350 Health Sciences Mall

35 Vancouver, B.C. Canada V6T $1 Z 3$

36 Phone number: 604-822-3365

37 Email address: moerman@zoology.ubc.ca

38 
42 It has been estimated that $15-30 \%$ of the $\sim 20,000$ genes in C. elegans are essential, yet many of

43 these genes remain to be identified or characterized. With the goal of identifying unknown

44 essential genes, we performed whole genome sequencing on complementation pairs from

45 legacy collections of maternal-effect lethal and sterile mutants. This approach uncovered

46 maternal genes required for embryonic development and genes with putative sperm-specific

47 functions. In total, 58 essential genes were identified on chromosomes III, IV, and V, of which 49

48 genes are represented by novel alleles in this collection. Of these 49 genes, 19 (40 alleles) were

49 selected for further functional characterization. The terminal phenotypes of embryos were

50 examined, revealing defects in cell division, morphogenesis, and osmotic integrity of the

51 eggshell. Mating assays with wild-type males revealed previously unknown male-expressed

52 genes required for fertilization and embryonic development. The result of this study is a

53 catalogue of mutant alleles in essential genes that will serve as a resource to guide further study

54 toward a more complete understanding of this important model organism. As many genes and

55 developmental pathways in C. elegans are conserved and essential genes are often linked to

56 human disease, uncovering the function of these genes may also provide insight to further our

57 understanding of human biology.

58

59

60 
61

62

63 Essential genes are those required for the survival or reproduction of an organism, and therefore

64 encode elements that are foundational to life. This class of genes has been widely studied for a

65 number of reasons. Essential genes are often well conserved and can offer insight into the

66 principles that govern common biological processes (Hughes 2002; Jordan et al. 2002; Georgi et

67 al. 2013). Researching these genes and their functions has important implications in

68 understanding the cellular and developmental processes that form complex organisms, including

69 humans. Additionally, identifying genes that are lethal when mutated opens up new avenues

70 through which drug development approaches can target parasites, pathogens, and cancer cells

71 (for example, Doyle et al. 2010; Shi et al. 2015; Vyas et al. 2015; Zhang et al. 2018). Finally, the

72 concept of a minimal gene set that is comprised of all genes necessary for life has been the

73 subject of much investigation and has recently been of particular interest in the field of synthetic

74 biology (reviewed in Ausländer et al. 2017).

75

76 Studying essential genes in humans is complicated by practical and ethical considerations.

77 Accordingly, model organisms have played a key role in identifying and understanding essential

78 genes, and efforts have been made to identify all essential genes in a few model organisms.

79 Systematic genome-wide studies of gene function in Saccharomyces cerevisiae have uncovered

80 more than 1,100 essential genes, many of which have phylogenetically conserved roles in

81 fundamental biological processes such as cell division, protein synthesis and metabolism

82 (Winzeler et al. 1999; Giaever et al. 2002; Yu et al. 2006; Li et al. 2011). While an important

83 contribution, this is only a fraction of the all the essential genes in multicellular organisms. In 
84 more complex model organisms, identifying all essential genes in the genome has not been so

85 straightforward. The discovery of RNA interference (RNAi; Fire et al. 1998) enabled researchers

86 to employ genome-wide reverse genetic screens to examine the phenotypic effects of gene

87 knockdown (Fraser et al. 2000; Kamath et al. 2003). In general, this has been an effective, high-

88 throughput method for identifying many genes with essential functions (Gönczy et al. 2000;

89 Sönnichsen et al. 2005). However, there are limitations to using RNAi to screen for all essential

90 genes, including incomplete gene knock down, off-target effects, and RNAi resistance in certain

91 tissue or cell types; thus, many genes of biological importance escape identification in high-

92 throughput RNAi screens. This highlights the motivation to obtain null alleles for every gene in

93 the genome, which has been the goal of several model organism consortia (C. elegans Deletion

94 Mutant Consortium 2012; Bradley et al. 2012; Varshney et al. 2013), though it has not yet been

95 achieved for any metazoan.

96

97 Caenorhabditis elegans has been an important model in developmental biology for decades, and

98 the ability to freeze and store populations of $C$. elegans indefinitely allows investigators to share

99 their original mutant strains with others around the world. In the first few decades of $C$. elegans

100 research, dozens of forward genetics screens were used to uncover mutants in hundreds of

101 essential genes (for example, Herman 1978; Meneely and Herman 1979; Rogalski et al. 1982;

102 Howell et al. 1987; Clark et al. 1988; Johnsen and Baillie 1988; Kemphues et al. 1988; McKim et

103 al. 1988; Howell and Rose 1990; Johnsen and Baillie 1991; McKim et al. 1992; Stewart et al.

104 1998; Gönczy et al. 1999). These early studies generated what we refer to here as legacy

105 collections. The alleles were often mapped to a region of the genome through deficiency or 
106 linkage mapping. However, the process of identifying the molecular nature of the genetic

107 mutations one-by-one using traditional methods was slow and laborious before the genome

108 sequence was complete (The C. elegans Sequencing Consortium 1998) and next-generation

109 sequencing technologies were developed (reviewed in Metzker 2010; Goodwin et al. 2016).

111 As whole genome sequencing (WGS) has become widely adopted, methods for identifying

112 mutant alleles have evolved to take advantage of these technological advances (Sarin et al. 2008;

113 Smith et al. 2008; Srivatsan et al. 2008; Blumenstiel et al. 2009; Schneeberger et al. 2009;

114 Doitsidou et al. 2010; Flibotte et al. 2010; Zuryn et al. 2010; Smith et al. 2016). With WGS

115 becoming increasingly affordable over time, mutant collections can now be mined for data in

116 efficient ways that were not possible two decades ago. Performing WGS on a single mutant

117 genome is often insufficient to identify a causal variant due to the abundance of background

118 mutations in any given strain, particularly one that has been subjected to random mutagenesis

119 (Denver et al. 2004; Hillier et al. 2008; Sarin et al. 2008; Flibotte et al. 2010). However, when

120 paired with additional strategies such as deletion or SNP-based mapping or bulk segregant

121 analysis, WGS becomes a valuable tool to expedite gene identification. Furthermore, if multiple

122 independently derived allelic mutants exist, an even simpler approach can be taken. By

123 sequencing two or more mutants within a complementation group and looking for mutations in

124 the same gene, the need for additional mapping or crossing schemes is greatly reduced

125 (Schneeberger et al. 2011; Nordström et al. 2013).

126 
127 In the legacy mutant collections described above, where large numbers of mutants are isolated,

128 it is feasible to obtain complementation groups with multiple alleles for many loci. In addition,

129 the abundance of mutants obtained in these large-scale genetic screens suggests that some

130 legacy mutant collections may harbor strains for which the mutations remain unidentified. If

131 such collections are coupled with thorough annotations, they are valuable resources that can be

132 mined with WGS. Indeed, some investigators have recently used such WGS-based approaches to

133 uncover novel essential genes from legacy collections (Jaramillo-Lambert et al. 2015; Qin et al.

134 2018). These projects bring us closer to identifying all essential genes in C. elegans and also

135 contribute to the ongoing efforts to obtain null mutations in every gene in the genome.

136

137 There are currently 3,755 C. elegans genes that have been annotated with lethal or sterile

138 phenotypes from RNAi knockdown studies (data from WormBase version WS275). In

139 comparison, the number of genes currently represented by lethal or sterile mutant alleles is

1401,885 (data from WormBase version WS275). These numbers should be considered minimums,

141 as the database annotations are not necessarily up to date. The discrepancy in these numbers

142 could be illustrative of the comparatively time-consuming and laborious nature of isolating and

143 identifying mutants. Additionally, some of the genes identified as essential in RNAi screens may

144 belong to paralogous gene families whose redundant functions are masked in single gene

145 knockouts. Although the total number of essential genes in C. elegans is unknown, extrapolation

146 from saturation mutagenesis screens has led to estimates that approximately $15-30 \%$ of the

$147 \sim 20,000$ genes in this organism are essential (Clark et al. 1988; Howell and Rose 1990; Johnsen

148 and Baillie 1997; The C. elegans Deletion Mutant Consortium 2012). This suggests the possibility 
149 that there are many essential genes in C. elegans that remain unidentified and/or lack

150 representation by a null allele.

151

152 In this study, we use WGS to revisit two C. elegans legacy mutant collections isolated more than

15325 years ago. These collections are a rich resource for essential gene discovery; they comprise 75

154 complementation groups in which at least two alleles with sterile or maternal-effect lethal

155 phenotypes have been found. With these collections, we sought to identify novel essential genes

156 and to conduct a preliminary characterization of their roles in fertilization and development.

157 Wild-type male rescue assays are used to attribute some mutant phenotypes to sperm-specific

158 genetic defects. In addition, we examine arrested embryos using differential interference

159 contrast (DIC) microscopy and document their terminal phenotypes. This work comprises a

160 catalogue of 123 alleles with mutations in 58 essential genes on chromosomes III, IV, and V. Of

161 these 58 genes, 49 are represented by novel alleles in this collection. We present several genes

162 which are reported here for the first time as essential genes and mutant alleles for genes that

163 have only previously been studied with RNAi knockdown. The aim of this work is to help

164 accelerate research efforts by identifying essential genes and providing an entry point into

165 further investigations of gene function. Advancing our understanding of essential genes is

166 imperative to reaching a more comprehensive knowledge of gene function in C. elegans and may

167 provide insight into conserved processes in developmental biology, parasitic nematology, and

168 human disease. 
MATERIALS AND METHODS

\section{Generation of legacy mutant collections}

172 Mutant strains were isolated in screens for maternal-effect lethal and sterile alleles in the early

173 1990s by Heinke Holzkamp and Ralf Schnabel (unpublished data), and Richard Feichtinger

174 (Feichtinger 1995). Two balancer strains were used for mutagenesis; GE1532: unc-32(e189)/qC1

175 [dpy-19(1259) glp-1(q339)] III; him-3(e1147) IV and GE1550: him-9(e1487) II; unc-

176 24(e138)/nT1[let(m435)] IV; dpy-11(e224)/nT1[let(m435)] V. These parental strains were

177 subjected to ethyl methanesulfonate (EMS) mutagenesis at $20^{\circ}$ as described by Brenner (1974),

178 with a mutagen dose of 50-75 mM and duration between 4 and 6 hours. Following mutagenesis,

179 L4 F1 animals were singled on plates at either $15^{\circ}$ or $17^{\circ}$. Animals with homozygous markers in

180 the F2 or F3 generation were transferred to $25^{\circ}$ and subsequently screened for the production of

181 dead eggs, unfertilized oocytes, or no eggs laid. The two mutant collections analyzed in this

182 study are summarized in Table 1.

183

184

185

186

187

188

189

190

191

\section{List of strains}

The wild-type Bristol N2 derivative PD1074 and strains with the following mutations were used:

him-3(e1147), unc-32(e189), qC1[dpy-19(e1259) glp-1(q339)], him-9(e1487), unc-24(e138), dpy11(e224, e1180), nT1[let(m435)] (IV;V), nT1[unc(n754)let] (IV;V). Strains carrying the following deletions were used for deficiency mapping: $n D f 16, n D f 40, s D f 110, s D f 125, t D f 5, t D f 6, t D f 7$ (III); eDf19, $n D f 41, s D f 2, s D f 21, s t D f 7(I V) ; c t D f 1, i t D f 2, n D f 32, s D f 28, s D f 35(V)$. All sDfs were kindly provided by D. Baillie's Lab (Simon Fraser University), and some strains were kindly provided by 
192 the Caenorhabditis Genetics Center (University of Minnesota). Nematode strains were cultured

193 as previously described by Brenner (1974).

194

195

196

197

198

199

200

201

202

203

204

205

206

207

208

209

210

211

212

213

214 new plates and those segregating viable Dpy and/or Unc progeny indicated complementation 215 between the two alleles.

216

\section{Outcrossing, mapping and complementation analysis}

All mutant strains were outcrossed at least once to minimize background mutations on other chromosomes. Hermaphrodites of the mutant strains were outcrossed with males of GE1532 for Collection A and males of GE1964: him-9(e1487) II; +/nT1[let(m435)] IV; dpy-

11(e1180)/nT1[let(m435)] V for Collection B. Deficiency mapping was used to localize mutations to a chromosomal region using the deletion strains listed above. A detailed description of the outcrossing and mapping schemes for Collection B can be found in Feichtinger (1995).

Complementation analysis of legacy mutants was performed by crossing 10 males of one mutant strain to 4 hermaphrodites of another strain. The presence of males with homozygous markers indicated successful crossing, and homozygous hermaphrodite progeny were transferred to new plates to determine whether viable offspring were produced and thus complementation occurred. Failure to complement was verified with additional homozygous animals or by repeating the cross. Complementation tests between CRISPR-Cas9 deletion strains and legacy mutants were performed by crossing heterozygous CRISPR-Cas9 deletion (GFP/+) males to heterozygous legacy mutant hermaphrodites. Twenty GFP hermaphrodite F1s were singled on 


\section{DNA extraction}

Balanced heterozygous strains were grown on $100 \mathrm{~mm}$ nematode growth medium (NGM) agar

221 plates (standard recipe with 3 times concentration of peptone) seeded with OP50 and harvested

222 at starvation. Genomic DNA was extracted using a standard isopropanol precipitation technique

223 previously described (Au et al. 2019). DNA quality was assessed with a NanoDrop 2000c

224 Spectrophotometer (Thermo Scientific) and DNA concentration was measured using a Qubit 2.0

225 Fluorometer and dsDNA Broad Range Assay kit (Life Technologies).

227 Whole genome sequencing and analysis pipeline

228 DNA library preparation and whole genome sequencing were carried out by The Centre for

229 Applied Genomics (The Hospital for Sick Children, Toronto, Canada). Between 20 and 33 C.

230 elegans mutant strains were run together on one lane of an Illumina HiSeq X to generate 150-bp

231 paired-end reads.

233 Sequencing analysis was done using a modified version of a previously designed custom pipeline

234 (Flibotte et al. 2010; Thompson et al. 2013). Reads were aligned to the C. elegans reference

235 genome (WS263; wormbase.org) using the short-read aligner BWA version 0.7.16 (Li and Durbin

236 2009). Single nucleotide variants (SNVs) and small insertions or deletions (indels) were called

237 using SAMtools toolbox version 1.6 (Li et al. 2009). To eliminate unreliable calls, variants at

238 genomic locations for which the canonical N2 strain has historically had low read depth or poor

239 quality (Thompson et al. 2013) were removed as potential candidates. The variant calls were

240 annotated with a custom Perl script and labeled heterozygous if represented by $20-80 \%$ of the 
241 reads at that location. The remaining candidates were then subjected to a series of custom

242 filters. Any variants that appeared in more than three strains from the same collection were

243 removed. The remaining list was filtered to only include heterozygous mutations affecting coding

244 exons (indels, missense and nonsense mutations) and splice sites (defined as the first two and

245 last two base pairs in an intron). Finally, the list of candidate mutations was trimmed to include

246 only mutations on the chromosome to which the mutation had originally been mapped.

\section{7}

248 For each pair of strains belonging to a complementation group, the final list of candidate

249 mutations was compared and the gene or genes in common were identified. In cases where

250 there was only one gene in common on both lists, this gene was designated the candidate

251 essential gene. For complementation groups with multiple candidate genes in common,

252 additional information such as the nature of the mutations and existing knowledge about the

253 genes was used to select a single candidate gene, when possible. When there was no gene

254 candidate in common within a pair of strains, the list of variants was reanalyzed to look for larger

255 deletions and rearrangements. If available, two additional alleles were sequenced to help

256 identify the gene.

258 Validation of gene identities

259 To validate the candidate gene identities derived from whole genome sequencing analysis, the

260 genomic position of each candidate gene was corroborated with the legacy data from deficiency

261 mapping experiments. Approximate boundaries for the deletions were estimated from the map 
262 coordinates of genes known to lie internal or external to the deletions according to data from

263 WormBase (WS275).

265 For further validation of select gene candidates, deletion mutants were generated in an N2 wild-

266 type background using a CRISPR-Cas9 genome editing strategy previously described (Norris et al.

267 2015; Au et al. 2019). Two guide RNAs were used to excise the gene of interest and replace it

268 with a selection cassette expressing G418 drug resistance and pharyngeal GFP (loxP + Pmyo-

269 2::GFP::unc-54 3'UTR + Prps-27::neoR::unc-543'UTR + loxP vector, provided by Dr. John Calarco,

270 University of Toronto, Canada). Guide RNAs were designed using the C. elegans Guide Selection

271 Tool (genome.sfu.ca/crispr) and synthesized by Integrated DNA Technologies (IDT). Repair

272 templates were generated by assembling homology arms (450-bp gBlocks synthesized by IDT)

273 and the selection cassette using the NEBuilder Hifi DNA Assembly Kit (New England Biolabs).

275 Cas9 protein (generously gifted from Dr. Geraldine Seydoux) was assembled into a

276 ribonucleoprotein (RNP) complex with the guide RNAs and tracrRNA (IDT) following the

277 manufacturer's recommendations. PD1074 animals were injected using standard microinjection

278 techniques (Mello et al. 1991; Kadandale et al. 2009) with an injection mix consisting of: $50 \mathrm{ng} / \mu \mathrm{l}$

279 repair template, $0.5 \mu \mathrm{M}$ RNP complex, $5 \mathrm{ng} / \mu \mathrm{l}$ pCFJ104 (Pmyo-3::mCherry), and $2.5 \mathrm{ng} / \mu \mathrm{l}$ pCFJ90

280 (Pmyo-2::mCherry). Injected animals were screened according to the protocol described in

281 Norris et al. (2015) and genomic edits were validated using the PCR protocol described in Au et

282 al. (2019). Complementation tests between CRISPR-Cas9 alleles and legacy mutant alleles were

283 performed to verify gene identities, as described above. 


\section{Analysis of orthologs, gene ontology, and expression patterns}

286 Previously reported phenotypes from RNAi experiments or mutant alleles were retrieved from

287 WormBase (WS275) and GExplore (genome.sfu.ca/gexplore; Hutter et al. 2009; Hutter and Suh

288 2016). Life stage-specific gene expression data from the modENCODE project (Hillier et al. 2009;

289 Gerstein et al. 2010, 2014; Boeck et al. 2016) were also accessed through GExplore. Visual

290 inspection of these data revealed genes with maternal expression patterns (high levels of

291 expression in the early embryo and hermaphrodite gonad) as well as those predominantly

292 expressed in males.

294 Human orthologs of C. elegans genes were determined using Ortholist 2 (ortholist.shaye-lab.org;

295 Kim et al. 2018). For maximum sensitivity, the minimum number of programs predicting a given

296 ortholog was set to one. NCBI BLASTp (blast.ncbi.nlm.nih.gov; Altschul et al. 1990) was used to

297 examine distributions of homologs across species and potential nematode-specificity in genes

298 with no human orthologs. Protein sequences from the longest transcript of each gene were used

299 to query the non-redundant protein sequences ( $\mathrm{nr}$ ) database, with default parameters and a

300 maximum of 1,000 target sequences. The results were filtered with an E-value threshold of $10^{-5}$.

301

302 Gene Ontology (GO) term analysis was performed using PANTHER version 16.0 (Thomas et al.

303 2003). The list of 58 candidate genes was used for an overrepresentation test, with the set of all

304 C. elegans genes as a background list. Overrepresentation was analyzed with a Fisher's Exact test

305 and p-values were adjusted with the Bonferroni multiple testing correction. 
307 Temperature sensitivity and mating assays

308 To assay temperature sensitivity, heterozygous strains were propagated at $15^{\circ}$ and homozygous

$309 L 4$ animals were isolated on $60 \mathrm{~mm}$ NGM plates $(2 \times 6 /$ plate or $3 \times 3 /$ plate $)$. After one week at

$31015^{\circ}$, plates were screened for the presence of viable homozygous progeny. If present, L4

311 homozygotes were transferred to new plates at $25^{\circ}$ and screened after three days to confirm

312 lethality or sterility.

314 Mating assays were carried out using PD1074 males and mutant hermaphrodites. Three L4-stage

315 homozygous mutant hermaphrodites were isolated and crossed with ten PD1074 males on each

316 of three $60 \mathrm{~mm}$ NGM plates. Control plates consisted of three L4 hermaphrodite mutants

317 without males. Mating assays were carried out at $25^{\circ} \mathrm{C}$ and observations were taken after three

318 days, noting the absence or presence of viable cross progeny.

320 Microscopy

321 The terminal phenotypes of dead eggs from maternal-effect lethal mutants were observed using

322 DIC microscopy. Young adult homozygous mutants were dissected to release their eggs in either

323 M9 buffer with Triton X-100 (0.5\%; M9+TX) or distilled water and embryos were left to develop

324 at $25^{\circ} \mathrm{C}$ overnight ( 16 hours). Embryos were mounted on $2 \%$ agarose pads and visualized using

325 a Zeiss Axioplan 2 equipped with DIC optics. Images of representative embryos were captured

326 using a Zeiss Axiocam 105 Color camera and ZEN 2.6 imaging software (Carl Zeiss Microscopy).

327 For embryos incubated in distilled water, an osmotic integrity defective (OID) phenotype was 
bioRxiv preprint doi: https://doi.org/10.1101/2021.06.16 448744; this version posted June 19, 2021. The copyright holder for this preprint (which was not certified by peer review) is the author/funder, who has granted bioRxiv a license to display the preprint in perpetuity. It is made available under aCC-BY 4.0 International license.

328 noted for embryos that burst or swelled and filled the eggshell, as described by Sönnichsen et al.

329 (2005).

330

331 Data availability

332 The raw sequence data from this study have been deposited in the NCBI Sequence Read Archive

333 (SRA; ncbi.nIm.nih.gov/sra) under accession number PRJNA628853. Supplemental material is

334 available at Figshare. File S1 contains sequences and associated information for CRISPR-Cas9

335 deletion alleles. File S2 contains life stage-specific expression patterns for the Genes of Interest.

336 File S3 contains documentation of the terminal phenotypes for maternal-effect lethal embryos. 


\section{RESULTS}

\section{Identification of 58 essential genes}

339 Whole genome sequencing was performed on a total of 157 strains, with depth of coverage

340 ranging between $21 x$ and $65 x$ (average $=38 x$ ). A minimum of two alleles for each of 75

341 complementation groups were sequenced and a total of 58 essential genes were identified

342 (Table 2). Literature searches revealed that 43 of these genes have been annotated with lethal or

343 sterile phenotypes from either mutant alleles or RNAi studies. Furthermore, 17 of the 157 alleles

344 had been previously sequenced (Vatcher et al. 1998; Gönczy et al. 2001; Kaitna et al. 2002;

345 Brauchle et al. 2003; Cockell et al. 2004; Delattre et al. 2004; Sonneville et al. 2004; Bischoff and

346 Schnabel 2006; Nieto et al. 2010), and therefore served as a blind test set to validate our analysis

347 approach. Eight of the nine genes represented in this blind test set were correctly identified by

348 our pipeline, whereas one gene escaped identification. This was due to an intronic mutation that

349 did not pass our filtering criteria but was found upon manual inspection of the sequencing data.

350 While the list of 58 genes includes many known essential genes, among the known genes are

351 alleles that are novel genetic variants. Nineteen genes from this collection which were not

352 previously studied or were not represented by lethal or sterile mutants were designated Genes

353 of Interest (GOI; Table 3). These $19 \mathrm{GOI}$, represented by 40 alleles, were further characterized as

354 part of this study. They include 14 genes (28 alleles) with a maternal-effect lethal phenotype and

3555 genes (12 alleles) with a sterile phenotype. 
358 After isolation, the mutant alleles were each localized to a chromosomal region through

359 deficiency mapping. This data was used to corroborate the candidate gene identities derived

360 from WGS analysis and to resolve complementation groups with more than one gene candidate.

361 For the majority of complementation groups, the genomic position of the assigned gene was in

362 agreement with the deficiency genetic mapping data (Figure 1).

363

364 There were some conflicts between the deficiency mapping data and the gene candidates

365 proposed through WGS analysis. Three complementation groups that were found to not map

366 under any of the tested deficiencies were assigned gene candidates whose genomic coordinates

367 fall into regions covered by the tested deficiencies (alleles of $b c k d-1 A$, top-3, and unc-112; Figure

368 1). In addition, two of these groups were assigned the same gene identity as another,

369 purportedly distinct, complementation group (Table 4). From WGS analysis, $b c k d-1 A$ was the

370 initial gene candidate for two different complementation groups, yet only one of these groups

371 had been mapped to a deletion (tDf5) that covers the bckd-1A locus. Similarly, top-3 was the

372 assigned gene candidate for three different complementation groups, only one of which was

373 mapped under a deficiency (tDf5) encompassing that gene. By performing complementation

374 tests with select alleles (Table 4), we concluded that the two $b c k d$-1A groups are not distinct, and

375 indeed they contain mutations in the same gene. One of the groups (gene-35) originally

376 identified as top-3 is a double mutant which fails to complement gene-15 (top-3) and gene-34

377 (unknown gene). 
379 Three candidate genes (nstp-2, C34D4.4 and F56D5.2) were selected for additional validation by

380 generating a deletion of the gene in a wild-type background using CRISPR-Cas9 genome editing

381 (Norris et al. 2015; Au et al. 2019). These genes were chosen because they were expected to be

382 of interest to the broader research community. The deletion alleles have been verified with the

383 PCR protocol described by Au et al. (2019). Guide RNA sequences and deletion-flanking

384 sequences are listed in Supplementary Table S1. Complementation testing between the newly

385 generated CRISPR-Cas9 deletion mutants and the legacy mutant strains confirmed that the

386 mutations are allelic, and the genes assigned to the legacy strains are correct (Supplementary

387 Table S1)

389 Human orthologs, gene ontology, and expression patterns

390 Of the 58 essential genes identified, 47 genes have predicted human orthologs (Table 2). Many

391 of these genes in humans have been implicated in disease and are associated with OMIM disease

392 phenotypes (Online Mendelian Inheritance in Man; omim.org). BLASTp searches revealed that

393 the set of $19 \mathrm{GOI}$ contains three nematode-specific genes (F56D5.2, perm-5, and T22B11.1) that

394 have homologs in parasitic species, and two uncharacterized genes (D2096.12 and Y54G2A.73)

395 that do not have significant homology outside the Caenorhabditis genus.

397 To gain insight into the functions of the identified essential genes, an overrepresentation test

398 was used to elucidate the most prominent gene ontology (GO) terms associated with them. The

399 Biological Process terms overrepresented in the set of 58 essential genes include such terms as

400 organelle organization (GO:0006996), nuclear division (GO:0000280), cellular metabolic process 
401 (GO:0044237), and DNA repair (GO:0006281), as shown in Figure 2. In the Molecular Function

402 category, binding (GO:0005488) and catalytic activity (GO:0003824) are overrepresented by 41

403 genes (adjusted $p=1.2 \mathrm{E}-07$ ) and 28 genes (adjusted $p=1.8 \mathrm{E}-03$ ), respectively.

404

405 To examine the timing of gene expression throughout the life cycle, gene expression data from

406 the modENCODE project (Hillier et al. 2009; Gerstein et al. 2010, 2014; Boeck et al. 2016) was

407 retrieved from GExplore (genome.sfu.ca/gexplore; Hutter et al. 2009; Hutter and Suh 2016) for

408 the $19 \mathrm{GOI}$ (Supplementary Appendix S2). These data show a U-shaped expression pattern for

409 ten of the GOI, with high expression occurring in the early embryonic stages as well as in

410 adulthood, and particularly in the hermaphrodite gonad. This U-shaped pattern is characteristic

411 of a maternal-effect gene, for which gene products are passed on to the embryo from the

412 parent. Five genes have a maternal gene expression pattern as well as expression throughout

413 other stages of the life cycle, indicating an additional, zygotic role for the gene. Seven genes have

414 elevated expression levels in males and L4-stage hermaphrodites. These genes are suspected to

415 be involved in sperm production or fertilization, and the associated strains were subjected to

416 mating assays (see below).

417

418 Temperature sensitivity and mating assays for genes of interest

419 The 40 alleles associated with the $19 \mathrm{GOI}$ were further examined to gain insight into the

420 phenotypic consequences of their mutations. Each allele was assayed for temperature

421 sensitivity, as some of the original mutant screening was carried out at $25^{\circ} \mathrm{C}$. Five alleles (marked

422 with a [ts] phenotype in Table 3) were deemed temperature sensitive and could proliferate as 
423 homozygotes at a permissive temperature of $15^{\circ} \mathrm{C}$, while being maternal-effect lethal or sterile

424 at a restrictive temperature of $25^{\circ} \mathrm{C}$. Curiously, four of these temperature sensitive alleles were

425 the results of stop codons, not missense mutations.

426

427 Seven candidate genes (16 alleles) were hypothesized to be involved in male fertility, based on

428 the production of unfertilized oocytes by hermaphrodites and/or predominantly male gene

429 expression patterns. These 16 strains were assayed for their ability to be rescued through mating

430 with wild-type males. 14 of the strains were rescued by the mating assay, while two strains failed

431 to rescue (Table 5). Phenotypic rescue through mating was consistent among alleles of the same

432 gene in five of the seven genes, while two genes had conflicting results among the pair of alleles

433 in their complementation groups (F56D5.2 and nstp-2).

\section{Terminal phenotypes of maternal-effect lethal embryos}

436 Using DIC microscopy, the terminal phenotypes of 28 maternal-effect lethal strains (a subset of

437 the $40 \mathrm{GOI}$ strains) were observed. Representative images were selected and compiled into a

438 catalogue of terminal phenotypes (Supplementary Appendix S3). Ten strains showed an osmotic

439 integrity defective (OID) phenotype (as described in Sönnichsen et al. 2005) in nearly all embryos

440 after incubation in distilled water, while three additional strains had only some embryos that

441 exhibited this phenotype (Table 3). The OID phenotype was evident in embryos that filled the

442 eggshell completely (for example, dgtr-1(t2043), Figure 3A) and eggs that burst in their

443 hypotonic surroundings. Early embryonic arrest was observed in embryos from the two dlat-1

444 mutant strains (t2035 and t2056), which arrested most often with only one to four cells (for 
bioRxiv preprint doi: https://doi.org/10.1101/2021.06.16.448744; this version posted June 19, 2021. The copyright holder for this preprint (which was not certified by peer review) is the author/funder, who has granted bioRxiv a license to display the preprint in perpetuity. It is made available under aCC-BY 4.0 International license.

445 example, Figure 3B). Eleven strains had embryos that terminated with approximately 100-200

446 cells (for example, ZK688.9(t1433), Figure 3C); while four strains developed into two- or three-

447 fold stage embryos that did not hatch and exhibited clear morphological defects, such as nstp-

$448 \quad 2($ t1835) with a lumpy body wall and constricted nose tip (Figure 3D).

449

450

451

452 
DISCUSSION

Revisiting legacy mutant collections with whole genome sequencing

457 In this study, we focused on reexamining legacy collections of C. elegans mutants isolated before

458 the complete genome sequence was published (The C. elegans Sequencing Consortium 1998)

459 and long before massively parallel sequencing was widely available. With major advances in

460 sequencing technology in the past 30 years (reviewed in Goodwin et al. 2016), WGS has become

461 affordable and accessible, making it possible to revisit past projects with new approaches and

462 advanced capabilities. We have sequenced paired alleles from 75 complementation groups on

463 chromosomes III, IV, and V, from which we identified 58 essential genes (Table 2).

465 While WGS is a powerful tool, it does not stand alone as a solution to identifying mutant alleles.

466 This study has shown the power of having multiple alleles in a complementation group when

467 faced with the abundance of genomic variants found in WGS analysis. Indeed, when we

468 sequenced four single alleles, which had no complementation pairs, we were unable to

469 designate a single mutation as the variant responsible for maternal-effect lethality (data not

470 shown). Our approach to gene identification proved to be effective and was validated by a

471 combination of different methods. The blind test set of 17 previously sequenced alleles from

472 which eight of nine genes were readily identified serves as an important validation of our

473 analysis pipeline and gives confidence in the results we obtained. In addition, the deficiency

474 mapping data, gene expression patterns from the modENCODE project, GO term analysis, and

475 phenotypes documented from previous experiments provide evidence to support the gene

476 identities we assigned in these mutant collections. 
478 The CRISPR-Cas9 deletion alleles we generated for selected gene candidates provide additional

479 validation and will be made available to the research community to serve as useful tools for

480 future studies. While the mutant alleles from the original study have been outcrossed, the

481 genetic balancer background and additional mutations that persist can complicate phenotypic

482 analysis. In contrast, these new CRISPR-Cas9 deletion strains were made in a wild-type

483 background, which makes it much easier to handle them and interpret their mutant phenotypes.

484 Furthermore, the pharyngeal GFP expression introduced by the gene editing approach acts as a

485 dominant and straightforward marker for tracking the alleles in a heterozygous population. This

486 is useful as the homozygous animals do not produce viable progeny.

487

488 The complementation groups that could not be assigned gene identities in our analysis may have

489 been complicated by variants in noncoding regions, poor sequencing coverage, or inaccurate

490 complementation pairing, among other possibilities. In future work, tracking down the genes we

491 were unable to identify will require repeating complementation tests and re-tooling the analysis

492 approach.

493

494 Gene ontology analysis reveals common themes and gaps in our knowledge

495 The underlying biological themes of the 58 essential genes were revealed by examining their GO

496 terms. The biological processes represented in Figure 2 help to confirm the nature of this set, as

497 a collection of genes that are required for essential functions such as cell division, metabolism,

498 and development. Performing GO-term analysis also revealed that a number of the genes in this 
499 collection lacked sufficient annotation to be interpreted this way. We found four genes about

500 which there is little to nothing known (D2096.12, F56D5.2, T22B11.1, and Y54G2A.73). For

501 example, F56D5.2 is a gene with no associated GO terms, no known protein domains, and no

502 orthologs in other model organisms. These wholly uncharacterized genes are intriguing

503 candidates which may help uncover new biological processes and biochemical pathways that are

504 evidently fundamental to life for this organism.

505

506 Examining expression patterns leads to discovery of genes involved in male fertility

507 The life stage-specific expression patterns (Supplementary Appendix S2) provide some insight

508 into the roles the genes in this collection play in development. 15 of the $19 \mathrm{GO}$ are highly

509 expressed in the early embryo and hermaphrodite gonad, which suggests that the gene product

510 is passed on to the embryo from the parent. Five of these maternal genes also have elevated

511 expression during late embryonic and larval stages, which suggests they are pleiotropic. The

512 zygotic functions of these genes must be non-essential or else a zygotic lethal, rather than

513 maternal-effect lethal, phenotype would be observed.

514

515 We also identified four genes that are most highly expressed in males and L4 hermaphrodites, as

516 well as three genes that have prominent male expression in addition to characteristic maternal

517 expression patterns. Mating assays confirmed that these male-expressed genes have an essential

518 role in male fertility. Studies have shown that genes expressed in sperm are largely insensitive to

519 RNAi (Fraser et al. 2000; Gönczy et al. 2000; Reinke et al. 2004; del Castillo-Olivares et al. 2009;

520 Zhu et al. 2009; Ma et al. 2014), making these types of genes particularly difficult to identify in 
521 high-throughput RNAi screens. With the availability of RNA-seq data across different life stages

522 for nearly every gene in the C. elegans genome (Hillier et al. 2009; Gerstein et al. 2010, 2014;

523 Boeck et al. 2016; Tintori et al. 2016; Packer et al. 2019), screening for characteristic gene

524 expression patterns may be a useful approach for identifying sterile and maternal-effect lethal

525 genes that remain to be discovered.

526

527 We propose that the seven male-expressed genes are involved in sperm production and/or

528 function (see Table 5). These genes are mostly uncharacterized, and this is the first reporting of

529 their involvement in male fertility. While the mutant hermaphrodites lay unfertilized oocytes (5

530 genes) or dead eggs (2 genes), this phenotype could be rescued in 14 of the 16 alleles by the

531 introduction of wild-type sperm through mating. The two alleles that could not be rescued had

532 allele pairs in the same complementation groups that were rescued in the mating assay. One of

533 these discrepancies, between F56D5.2(t1744) and F56D5.2(t1791), was resolved when we found

534 a second mutation in a nearby essential gene that was likely responsible for the inability of one

535 strain to be rescued (data not shown). The presence of additional lethal mutations in the

536 genome is unsurprising given the nature of chemical mutagenesis, and it reinforces the

537 advantage of having multiple alleles for a gene when interpreting mutant phenotypes.

539 Interpreting terminal phenotypes of maternal-effect lethal mutants

540 The catalogue of terminal phenotypes (Supplementary Appendix S3) created in this study

541 provides a window into the roles the maternal-effect genes play in development. Some of these

542 phenotypes corroborate previously observed phenotypes from RNAi studies. For example, RNAi 
543 knockdown experiments have shown that DLAT-1 is an enzyme involved in metabolic processes

544 required for cell division in one-cell C. elegans embryos (Rahman et al. 2014). We uncovered two

545 alleles of dlat-1 in this study (t2035 and t2056) in which most embryos arrest at the one- to four-

546 cell stage (Figure 3B). The mutant alleles presented here can confirm previously reported

547 phenotypes and serve as new genetic tools for continuing the study of essential gene function.

549 We also identified alleles for six genes that exhibit an osmotic integrity defective (OID)

550 phenotype, resulting in embryos that filled the eggshell completely or burst in distilled water.

551 More than 100 genes have been identified in RNAi screens as important for the osmotic integrity

552 of developing embryos (reviewed in Stein and Golden 2018). Some of these genes have roles in

553 lipid metabolism (Rappleye et al. 2003; Benenati et al. 2009), cellular trafficking (Rappleye et al.

554 1999), and chitin synthesis (Johnston et al. 2006). Four of the six genes identified with OID

555 mutants in this study have been previously implicated in osmotic sensitivity: $d g$ tr-1 is involved in

556 lipid biosynthesis (Carvalho et al. 2011; Olson et al. 2012), trcs-1 is involved in lipid metabolism

557 and membrane trafficking (Green et al. 2011); perm-5 is predicted to have lipid binding activity;

558 and F21D5.1 is an ortholog of human PGM3, an enzyme involved in the hexosamine pathway

559 which generates substrates for chitin synthase. We found OID mutants for two additional genes

560 that were not previously characterized with this phenotype, $b c k d-1 A$ and $02096.12 . b c k d-1 A$ is a

561 component of the branched-chain alpha-keto dehydrogenase complex, which is involved in fatty

562 acid biosynthesis (Kniazeva et al. 2004); this may be indicative of a role in generating or

563 maintaining the lipid-rich permeability barrier. D2096.12 is a Caenorhabditis-specific gene with

564 no known protein domains. Elucidating the function of this uncharacterized gene may lead to 
565 new insights about the biochemistry of eggshell formation and permeability in C. elegans

566 embryos.

567

568 Most of the mutant strains we examined with DIC microscopy arrested around the 100- to 200-

569 cell stage as a seemingly disorganized group of cells (for example, Figure 3C). Others developed

570 into two-fold or later stage embryos that moved inside the eggshell but did not hatch (for

571 example, Figure 3D). The terminal phenotypes documented here reveal how long the embryo

572 can persist without the maternal contribution of gene products, and the developmental defects

573 that ensue. Future studies might make use of fluorescent markers and automated cell lineage

574 tracking (for example, Thomas et al. 1996; Schnabel et al. 1997; Bao et al. 2006; Wang et al.

575 2019) as well as single-cell transcriptome data (Tintori et al. 2016; Packer et al. 2019) to further

576 investigate these essential genes.

\section{7}

\section{Relevance beyond C. elegans}

579 In this collection of 58 essential genes, there are 47 genes (81\%) with human orthologs; a two-

580 fold enrichment when compared to all C. elegans genes, $41 \%$ of which have human orthologs

581 (Kim et al. 2018). This is in line with previous findings that essential genes are more often

582 phylogenetically conserved than non-essential genes (Hughes 2002; Jordan et al. 2002; Georgi et

583 al. 2013). Essential genes in model organisms are often associated with human diseases (Culetto

584 and Sattelle 2000; Silverman et al. 2009; Dickerson et al. 2011; Qin et al. 2018), making the

585 alleles identified in this study potentially relevant to understanding human health. Indeed, there

586 are OMIM disease phenotypes associated with a number of the human orthologs identified in 
587 Table 2. Novel mutant alleles in C. elegans may help us better understand genetic disorders by

588 providing new opportunities to interrogate gene function, explore genetic interactions, and

589 screen prospective therapeutics.

590

591 Nematode-specific genes that are essential are important to nematode biology in general and

592 are particularly relevant in parasitic nematology. We found three genes in our GOI list (F56D5.2,

593 perm-5, and T22B11.1) that have orthologs in parasitic nematode species and not in other phyla.

594 With growing anthelminthic drug resistance around the world (Jabbar et al. 2006), novel

595 management strategies are needed to combat parasitic nematodes, which infect crops,

596 livestock, and people worldwide (Nicol et al. 2011; Wolstenholme et al. 2004; Hotez et al. 2008).

597 Essential genes are desirable targets for drug development, yet identifying such genes in

598 parasites experimentally is difficult (Kumar et al. 2007; Doyle et al. 2010). Thus, as a free-living

599 nematode, C. elegans is a widely used model for genetically intractable parasitic species (Bürglin

600 et al. 1998; Hashmi et al. 2001). Our identification of novel essential genes with orthologs in

601 parasitic nematodes may provide new opportunities to explore management strategies.

602

603 It is our hope that the alleles and phenotypes presented here will serve as a starting point and

604 guide future research to elucidate the specific roles these genes play in embryogenesis. All of the

605 alleles presented in this study are available to the research community through the

606 Caenorhabditis Genetics Center (cgc.umn.edu) and we anticipate they will serve as a valuable

607 resource in the years to come. The wealth of material uncovered in this specific legacy collection

608 will hopefully inspire similar explorations of other frozen mutant collections. 
612 The authors thank Mark L. Edgley for advice and help with strain maintenance, as well as Negin

613 Khosravi, who replicated some of the nematode assays and conducted PCR assays with

614 F56D5.2(t1744) to reveal an additional mutation in a nearby an essential gene. This work was

615 supported by a CIHR Canada Graduate Scholarship-Master's (awarded to EL) and CIHR grant PJT-

616148549 (awarded to DGM). This work was also supported by a grant from NSERC to DGM and an

617 R24 NIH grant 5R240D023041 (awarded to Ann Rougvie, Paul Sternberg, Geraldine Seydoux and

618 DGM). 
bioRxiv preprint doi: https://doi.org/10.1101/2021.06.16.448744; this version posted June 19, 2021. The copyright holder for this preprint (which was not certified by peer review) is the author/funder, who has granted bioRxiv a license to display the preprint in perpetuity. It is made available under aCC-BY 4.0 International license.

TABLES

620

621 Table 1. Summary of mutant collections

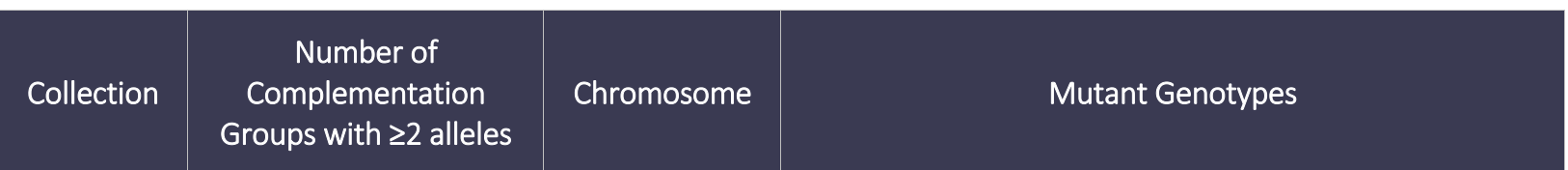

\begin{tabular}{|c|c|c|c|}
\hline A & 32 & III & unc-32(e189) let(t...)/qC1 III; him-3(e1147) IV \\
\hline \multirow{2}{*}{ B } & 25 & IV & $\begin{array}{c}\text { him-9(e1487) II; unc-24(e138) let(t...)/nT1 [let(m435)] } \\
\text { IV; dpy-11(e224)/nT1 [let(m435)] V }\end{array}$ \\
\hline & 18 & V & $\begin{array}{c}\operatorname{him}-9(e 1487) \text { II; unc-24(e138)/nT1 [let(m435)] IV; dpy- } \\
\text { 11(e224) let(t...)/nT1 [let(m435)] V }\end{array}$ \\
\hline
\end{tabular}


624 Table 2. List of 58 essential genes with associated maternal-effect lethal or sterile alleles

\begin{tabular}{|c|c|c|c|c|c|c|c|c|c|c|c|c|c|}
\hline Group & Strain & Allele(s) & Gene & Chr. & Position & \multicolumn{2}{|c|}{$\begin{array}{c}\text { Base } \\
\text { Change }\end{array}$} & Mutation & $\begin{array}{l}\text { Mutation } \\
\text { Type }\end{array}$ & $\begin{array}{c}\text { Amino } \\
\text { Acid }^{+} \\
\text {Change }^{+}\end{array}$ & $\begin{array}{l}\text { Protein Size } \\
\text { (Amino Acids) }^{\dagger}\end{array}$ & $\begin{array}{c}\text { Human } \\
\text { Ortholog(s) }\end{array}$ & $\begin{array}{l}\text { Associated OMIM } \\
\text { phenotype(s) }^{\ddagger}\end{array}$ \\
\hline \multirow{2}{*}{ Y } & GE2430 & t2135 & air-1 & V & 8221773 & C & $\mathrm{T}$ & SNV & missense & $\mathrm{R} 62 \mathrm{C}$ & \multirow{2}{*}{326} & \multirow{2}{*}{$\begin{array}{l}\text { AURKA, } \\
\text { AURKB, } \\
\text { AURKC, } \\
\text { STK36 }\end{array}$} & \multirow{2}{*}{$\begin{array}{c}\text { Colorectal cancer, } \\
\text { susceptibility to [114500]; } \\
\text { Spermatogenic failure } 5 \\
{[243060]}\end{array}$} \\
\hline & GE2337 & t2095 & air-1 & V & 8223169 & CAT & C & deletion & frameshift & - & & & \\
\hline \multirow[b]{2}{*}{$x$} & GE2314 & t1724 & aptf-2 & IV & 13414105 & A & G & SNV & missense & L244P & \multirow[b]{2}{*}{367} & \multirow{2}{*}{$\begin{array}{l}\text { TFAP2A, } \\
\text { TFAP2B, } \\
\text { TFAP2C, } \\
\text { TFAP2D, } \\
\text { TFAP2E }\end{array}$} & \multirow{2}{*}{$\begin{array}{c}\text { Char syndrome [169100]; } \\
\text { Patent ductus arteriosus } 2 \\
\text { [617035]; Branchiooculofacial } \\
\text { syndrome [113620] }\end{array}$} \\
\hline & GE2289 & t1836 & aptf-2 & IV & 13414263 & G & $\mathrm{T}$ & SNV & nonsense & C191* & & & \\
\hline \multirow{2}{*}{$\mathrm{H}$} & GE1958 & $\mathrm{t} 1726$ & atg-7 & IV & 11079764 & G & A & SNV & nonsense & Q367* & \multirow{2}{*}{647} & \multirow{2}{*}{ ATG7 } & \multirow{2}{*}{ (none) } \\
\hline & GE1936 & t1738 & atg-7 & IV & 11079973 & C & $\mathrm{T}$ & SNV & nonsense & W311* & & & \\
\hline \multirow{2}{*}{$\mathrm{T}$} & GE2449 & t2143 & atl-1 & V & 9635587 & C & $\mathrm{T}$ & SNV & nonsense & W2346* & \multirow{2}{*}{2531} & \multirow{2}{*}{ ATR, PRKDC } & \multirow{2}{*}{$\begin{array}{l}\text { Cutaneous telangiectasia and } \\
\text { cancer syndrome, familial } \\
\text { [614564]; Seckel syndrome } 1 \\
\text { [210600]; Immunodeficiency } \\
26 \text { with or without neurologic } \\
\text { abnormalities [615966] }\end{array}$} \\
\hline & GE2467 & t2155 & atl-1 & V & 9637978 & C & $\mathrm{T}$ & SNV & missense & E1710K & & & \\
\hline \multirow{2}{*}{$\begin{array}{l}\text { gene- } \\
28\end{array}$} & GE2200 & t1480 & bckd-1A & III & 12969933 & G & A & SNV & nonsense & Q174* & \multirow{4}{*}{432} & \multirow{4}{*}{$\begin{array}{l}\text { BCKDHA, } \\
\text { TMEM91, } \\
\text { AC011462.1 }\end{array}$} & \multirow{4}{*}{$\begin{array}{l}\text { Maple syrup urine disease } \\
\qquad[248600]\end{array}$} \\
\hline & GE1742 & t1461 & bckd-1A & III & 12971429 & G & $A$ & SNV & nonsense & Q109* & & & \\
\hline \multirow{2}{*}{$\begin{array}{l}\text { gene- } \\
17\end{array}$} & GE2206 & t1514 & bckd-1A & III & 12971273 & G & $A$ & SNV & nonsense & Q161* & & & \\
\hline & GE2627 & t1603 & bckd-1A & III & 12971305 & C & $\mathrm{T}$ & SNV & nonsense & W150* & & & \\
\hline \multirow[b]{2}{*}{ VZ } & GE2890 & t1821 & C34D4.4 & IV & 7150054 & G & $A$ & SNV & nonsense & W101* & \multirow[b]{2}{*}{205} & \multirow{2}{*}{$\begin{array}{l}\text { TVP23A, } \\
\text { TVP23B, } \\
\text { TVP23C, } \\
\text { TVP23C- } \\
\text { CDRT4 }\end{array}$} & \multirow[b]{2}{*}{ (none) } \\
\hline & GE2840 & t1860 & C34D4.4 & IV & 7150143 & G & $A$ & SNV & nonsense & W131* & & & \\
\hline \multirow{3}{*}{ a } & GE2734 & t2029 & С56А3.8 & V & 13560728 & G & $A$ & SNV & missense & G62E & \multirow{3}{*}{402} & \multirow{3}{*}{$\begin{array}{l}\text { PI4K2A, } \\
\text { PI4K2B }\end{array}$} & \multirow{3}{*}{ (none) } \\
\hline & GE2886 & t2055 & C56А3.8 & V & 13560787 & G & $A$ & SNV & missense & E243K & & & \\
\hline & GE2487 & t2149 & C56A3.8 & V & 13561369 & C & $\mathrm{T}$ & SNV & missense & P82L & & & \\
\hline$y$ & GE2142 & t2074 & $c c z-1$ & V & 13679756 & $\mathrm{~T}$ & A & SNV & nonsense & Y248* & \multirow{2}{*}{528} & \multirow{2}{*}{ CCZ1, CCZ1B } & (noprot \\
\hline v & GE2304 & t2129 & $c c z-1$ & V & 13680792 & C & $\mathrm{T}$ & SNV & nonsense & Q361* & & & (none) \\
\hline
\end{tabular}




\begin{tabular}{|c|c|c|c|c|c|c|c|c|c|c|c|c|c|}
\hline Group & Strain & Allele(s) & Gene & Chr. & Position & \multicolumn{2}{|c|}{$\begin{array}{l}\text { Base } \\
\text { Change }\end{array}$} & Mutation & $\begin{array}{l}\text { Mutation } \\
\text { Type }\end{array}$ & $\begin{array}{l}\text { Amino } \\
\text { Acid } \\
\text { Change }^{+}\end{array}$ & $\begin{array}{l}\text { Protein Size } \\
\text { (Amino Acids) }^{\dagger}\end{array}$ & $\begin{array}{l}\text { Human } \\
\text { Ortholog(s) }\end{array}$ & $\begin{array}{l}\text { Associated OMIM } \\
\text { phenotype(s) }\end{array}$ \\
\hline \multirow{2}{*}{$b$} & GE2047 & t2021 & cept-2 & V & 14349388 & G & A & SNV & nonsense & W128* & \multirow{2}{*}{424} & \multirow{2}{*}{$\begin{array}{l}\text { CEPT1, } \\
\text { CHPT1, } \\
\text { SELENOI }\end{array}$} & \multirow{2}{*}{$\begin{array}{l}\text { Spastic paraplegia 81, } \\
\text { autosomal recessive [618768] }\end{array}$} \\
\hline & GE2122 & t2007 & cept-2 & V & 14349747 & G & A & SNV & splice site & - & & & \\
\hline \multirow{2}{*}{$\begin{array}{c}\text { gene- } \\
4\end{array}$} & GE2275 & t1517 & cls-2 & III & 9055405 & G & A & SNV & missense & R102Q & \multirow{2}{*}{1023} & \multirow{2}{*}{$\begin{array}{l}\text { CLASP1, } \\
\text { CLASP2 }\end{array}$} & \multirow{2}{*}{ (none) } \\
\hline & GE2357 & t1527 & cls-2 & III & 9055440 & G & A & SNV & missense & G114R & & & \\
\hline \multirow{2}{*}{$R$} & GE2082 & t2053 & cpl-1 & V & 16593886 & G & A & SNV & missense & S148F & \multirow{2}{*}{337} & \multirow{2}{*}{$\begin{array}{l}\text { CTSF, CTSK, } \\
\text { CTSL, CTSS, } \\
\text { CTSV }\end{array}$} & \multirow{2}{*}{$\begin{array}{c}\text { Pycnodysostosis [265800]; } \\
\text { Ceroid lipofuscinosis, neuronal, } \\
13 \text { [615362] }\end{array}$} \\
\hline & GE2451 & t2144 & cpl-1 & V & 16595201 & G & $A$ & SNV & nonsense & Q49* & & & \\
\hline \multirow{2}{*}{ A } & GE2447 & t1879 & cpt-2 & IV & 11180120 & C & $\mathrm{T}$ & SNV & nonsense & Q141* & \multirow{2}{*}{646} & \multirow{2}{*}{ СРT2 } & \multirow{2}{*}{$\begin{array}{l}\text { Carnitine palmitoyltransferase } \\
\text { II deficiency [600649, 608836, } \\
\text { 255110]; Encephalopathy, } \\
\text { acute, infection-induced, } \\
\text { susceptibility to, } 4 \text { [614212] }\end{array}$} \\
\hline & GE1938 & t1742 & cpt-2 & IV & 11180603 & G & $A$ & SNV & nonsense & W194* & & & \\
\hline \multirow{2}{*}{$\begin{array}{l}\text { gene- } \\
24\end{array}$} & GE2657 & t1704 & cra-1 & III & 6867181 & G & A & SNV & nonsense & Q525* & \multirow{2}{*}{958} & \multirow{2}{*}{ NAA25 } & \multirow{2}{*}{ (none) } \\
\hline & GE2242 & t1618 & cra-1 & III & 6868737 & C & $\mathrm{T}$ & SNV & nonsense & W149* & & & \\
\hline \multirow{3}{*}{$\mathrm{D}$} & GE1929 & t1729 & csr-1 & IV & 7960467 & $\mathrm{~T}$ & A & SNV & missense & N708K & \multirow{3}{*}{1030} & \multirow{3}{*}{ (none) } & \multirow{3}{*}{ (none) } \\
\hline & GE1929 & t1729 & csr-1 & IV & 7961246 & G & A & SNV & missense & G922E & & & \\
\hline & GE2452 & t1897 & csr-1 & IV & 7959252 & G & A & SNV & splice site & - & & & \\
\hline \multirow{2}{*}{$\begin{array}{l}\text { gene- } \\
25\end{array}$} & GE2595 & $\begin{array}{l}\mathrm{t} 1662 \\
\mathrm{t} 1718\end{array}$ & cup-5 & III & 7585568 & C & $\mathrm{T}$ & SNV & nonsense & $\mathrm{R} 263^{*}$ & \multirow{2}{*}{668} & \multirow{2}{*}{$\begin{array}{l}\text { MCOLN1, } \\
\text { MCOLN2, } \\
\text { MCOLN3 }\end{array}$} & \multirow{2}{*}{ Mucolipidosis IV [252650] } \\
\hline & GE2355 & t1528 & cup-5 & III & 7590536 & G & A & SNV & splice site & - & & & \\
\hline \multirow{2}{*}{$\begin{array}{l}\text { gene- } \\
30\end{array}$} & GE2345 & t1525 & cyk-3 & III & 6020590 & C & $\mathrm{T}$ & SNV & nonsense & Q98* & \multirow{2}{*}{1178} & USP15, & \\
\hline & GE2352 & t1535 & cyk-3 & III & 6022863 & G & A & SNV & nonsense & W723* & & USP32, USP6 & (none) \\
\hline & GE2499 & t1877 & D2096.12 & IV & 8363937 & C & $\mathrm{T}$ & SNV & nonsense & Q126* & & & \\
\hline J & GE2407 & t1906 & D2096.12 & IV & 8365654 & $\mathrm{~T}$ & $A$ & SNV & nonsense & L638* & 163 & (none) & (none) \\
\hline & GE2135 & t2043 & dgtr-1 & V & 6497335 & G & $A$ & SNV & splice site & - & & $\begin{array}{l}\text { AWAT1, } \\
\text { AWAT2, } \\
\text { DGAT2, }\end{array}$ & \\
\hline $\mathrm{O}$ & GE2063 & t2042 & dgtr-1 & V & 6498186 & G & $A$ & SNV & missense & G310R & 359 & $\begin{array}{l}\text { DGAT2L6, } \\
\text { MOGAT1, } \\
\text { MOGAT2, } \\
\text { MOGAT3 }\end{array}$ & (none) \\
\hline
\end{tabular}




\begin{tabular}{|c|c|c|c|c|c|c|c|c|c|c|c|c|c|}
\hline Group & Strain & Allele(s) & Gene & Chr. & Position & \multicolumn{2}{|c|}{$\begin{array}{l}\text { Base } \\
\text { Change }\end{array}$} & Mutation & $\begin{array}{l}\text { Mutation } \\
\text { Type }\end{array}$ & $\begin{array}{l}\text { Amino } \\
\text { Acid } \\
\text { Change }^{+}\end{array}$ & $\begin{array}{l}\text { Protein Size } \\
\text { (Amino Acids) }^{\dagger}\end{array}$ & $\begin{array}{c}\text { Human } \\
\text { Ortholog(s) }\end{array}$ & $\begin{array}{l}\text { Associated OMIM } \\
\text { phenotype(s) }\end{array}$ \\
\hline \multirow{2}{*}{$\mathrm{C}$} & GE2028 & t1801 & dif-1 & IV & 7552230 & A & C & SNV & nonsense & Y187* & \multirow{2}{*}{312} & \multirow{2}{*}{ SLC25A20 } & \multirow{2}{*}{$\begin{array}{c}\text { Carnitine-acylcarnitine } \\
\text { translocase deficiency } \\
{[212138]}\end{array}$} \\
\hline & GE1932 & t1732 & dif-1 & IV & 7552641 & C & $\mathrm{T}$ & SNV & missense & G75D & & & \\
\hline \multirow{2}{*}{$\begin{array}{l}\text { gene- } \\
13\end{array}$} & GE2612 & $\mathrm{t} 1676$ & div-1 & III & 10245480 & G & A & SNV & nonsense & Q489* & \multirow{2}{*}{581} & \multirow{2}{*}{ POLA2 } & \multirow{2}{*}{ (none) } \\
\hline & GE2577 & t1642 & div-1 & III & 10248544 & C & $\mathrm{T}$ & SNV & start ATG & M1I & & & \\
\hline \multirow{2}{*}{$d$} & GE2335 & t2056 & dlat-1 & V & 14445907 & $\mathrm{G}$ & $A$ & SNV & nonsense & Q419* & \multirow{2}{*}{507} & \multirow{2}{*}{ DLAT } & \multirow{2}{*}{$\begin{array}{c}\text { Pyruvate dehydrogenase E2 } \\
\text { deficiency [245348] }\end{array}$} \\
\hline & GE2541 & t2035 & dlat-1 & V & 14446981 & G & A & SNV & missense & P83L & & & \\
\hline \multirow{2}{*}{ u } & GE2402 & t1940 & F21D5.1 & IV & 8727315 & C & $\mathrm{T}$ & SNV & missense & A436V & \multirow{2}{*}{550} & \multirow{2}{*}{ PGM3 } & \multirow{2}{*}{ Immunodeficiency 23 [615816 } \\
\hline & GE2445 & t1935 & F21D5.1 & IV & 8727668 & C & $\mathrm{T}$ & SNV & missense & L539F & & & \\
\hline \multirow{2}{*}{$t$} & GE2837 & t1791 & F56D5.2 & IV & 9397791 & G & A & SNV & nonsense & Q214* & \multirow{2}{*}{385} & \multirow{2}{*}{ (none) } & \multirow{2}{*}{ (none) } \\
\hline & GE2881 & t1744 & F56D5.2 & IV & 9398158 & G & A & SNV & missense & S107F & & & \\
\hline \multirow{2}{*}{$\begin{array}{l}\text { gene- } \\
26\end{array}$} & GE1715 & t1436 & gsp-2 & III & 7337087 & C & $\mathrm{T}$ & SNV & nonsense & R95* & \multirow{2}{*}{333} & \multirow{2}{*}{$\begin{array}{l}\text { PPP1CA, } \\
\text { PPP1CB, } \\
\text { PPP1CC }\end{array}$} & \multirow{2}{*}{$\begin{array}{c}\text { Noonan syndrome-like } \\
\text { disorder with loose anagen } \\
\text { hair } 2 \text { [617506] }\end{array}$} \\
\hline & GE2360 & t1481 & gsp-2 & III & 7337383 & G & A & SNV & missense & G174E & & & \\
\hline \multirow{2}{*}{$\begin{array}{l}\text { gene- } \\
32\end{array}$} & GE2545 & t1577 & gsr-1 & III & 3652401 & G & A & SNV & missense & G335R & \multirow{2}{*}{473} & \multirow{2}{*}{$\begin{array}{l}\text { GSR, } \\
\text { TXNRD1, } \\
\text { TXNRD2, } \\
\text { TXNRD3 }\end{array}$} & \multirow{2}{*}{$\begin{array}{l}\text { Hemolytic anemia due to } \\
\text { glutathione reductase } \\
\text { deficiency [618660]; } \\
\text { Glucocorticoid deficiency } 5 \\
\text { [617825] }\end{array}$} \\
\hline & GE2644 & t1594 & gsr-1 & III & 3652407 & C & $\mathrm{T}$ & SNV & nonsense & R337* & & & \\
\hline \multirow{2}{*}{$\begin{array}{l}\text { gene- } \\
31\end{array}$} & GE2583 & t1654 & hcp-3 & III & 9615498 & G & A & SNV & missense & R269C & 200 & & \\
\hline & GE2692 & t1717 & hcp-3 & III & 9615555 & C & $\mathrm{T}$ & SNV & missense & E250K & & CLIVI & (1110110) \\
\hline C & GE2455 & t1914 & klp-18 & IV & 7040335 & $\mathrm{~T}$ & C & SNV & missense & $\mathrm{Y} 42 \mathrm{H}$ & & VIr & (non \\
\hline U & GE2000 & t1795 & klp-18 & IV & 7041203 & G & A & SNV & missense & E316K & 932 & RIF & (mone) \\
\hline & GE2367 & $\mathrm{t} 1563$ & klp-19 & III & 13306451 & A & $\mathrm{T}$ & SNV & missense & $\mathrm{L} 230 \mathrm{H}$ & & & \\
\hline $\begin{array}{l}\text { gene- } \\
\quad 6\end{array}$ & GE2367 & t1563 & klp-19 & III & 13306457 & G & A & SNV & missense & $A 228 \mathrm{~V}$ & 1083 & KIF4A, KIF4B & $\begin{array}{c}\text { Mental retardation, X-linked } \\
100[300923]\end{array}$ \\
\hline & GE2264 & t1628 & klp-19 & III & 13306872 & C & $\mathrm{T}$ & SNV & missense & G90R & & & \\
\hline 1 & GE2003 & t1817 & let-99 & IV & 12569291 & C & $\mathrm{T}$ & SNV & nonsense & Q447* & & (nt & 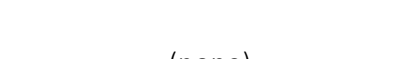 \\
\hline 1 & GE2514 & t1912 & let-99 & IV & 12570199 & C & $\mathrm{T}$ & SNV & missense & L617F & 098 & (none) & (none) \\
\hline
\end{tabular}




\begin{tabular}{|c|c|c|c|c|c|c|c|c|c|c|c|c|c|}
\hline Group & Strain & Allele(s) & Gene & Chr. & Position & \multicolumn{2}{|c|}{$\begin{array}{l}\text { Base } \\
\text { Change }\end{array}$} & Mutation & $\begin{array}{l}\text { Mutation } \\
\text { Type }\end{array}$ & $\begin{array}{c}\text { Amino } \\
\text { Acid }^{+} \\
\text {Change }^{\dagger}\end{array}$ & $\begin{array}{l}\text { Protein Size } \\
\text { (Amino Acids) }^{\dagger}\end{array}$ & $\begin{array}{l}\text { Human } \\
\text { Ortholog(s) }\end{array}$ & $\begin{array}{l}\text { Associated OMIM } \\
\text { phenotype(s) }\end{array}$ \\
\hline \multirow{2}{*}{$\begin{array}{c}\text { gene- } \\
22\end{array}$} & GE2730 & t1550 & lis-1 & III & 13375376 & C & $\mathrm{T}$ & SNV & nonsense & W92* & \multirow{2}{*}{404} & \multirow{2}{*}{ PAFAH1B1 } & \multirow{2}{*}{$\begin{array}{l}\text { Lissencephaly 1; Subcortical } \\
\text { laminar heterotopia [607432] }\end{array}$} \\
\hline & GE2653 & t1698 & lis-1 & III & 13375401 & C & $\mathrm{T}$ & SNV & splice site & - & & & \\
\hline \multirow{2}{*}{ z } & GE2130 & t1765 & mbk-2 & IV & 13033086 & C & $\mathrm{T}$ & SNV & missense & R533C & \multirow{2}{*}{817} & \multirow{2}{*}{$\begin{array}{l}\text { DYRK2, } \\
\text { DYRK3, } \\
\text { DYRK4 }\end{array}$} & \multirow{2}{*}{ (none) } \\
\hline & GE2503 & t1888 & mbk-2 & IV & 13033644 & C & $\mathrm{T}$ & SNV & missense & P701L & & & \\
\hline \multirow{2}{*}{$\begin{array}{c}\text { gene- } \\
10\end{array}$} & GE2740 & t1576 & mel-32 & III & 6440655 & C & $\mathrm{T}$ & SNV & missense & G395R & \multirow{2}{*}{507} & \multirow{2}{*}{$\begin{array}{l}\text { SHMT1, } \\
\text { SHMT2 }\end{array}$} & \multirow{2}{*}{ (none) } \\
\hline & GE1731 & t1456 & mel-32 & III & 6440831 & C & $\mathrm{T}$ & SNV & missense & G336E & & & \\
\hline \multirow{2}{*}{ M } & GE1999 & t1793 & mex-5 & IV & 13354014 & $\mathrm{~T}$ & G & SNV & nonsense & Y79* & \multirow{2}{*}{468} & \multirow{2}{*}{ (none) } & \multirow{2}{*}{ (none) } \\
\hline & GE2093 & t1800 & mex-5 & IV & 13354478 & $\mathrm{~T}$ & A & SNV & nonsense & L219* & & & \\
\hline \multirow{2}{*}{$S$} & GE2511 & t2162 & mom-2 & V & 8356808 & $\mathrm{~T}$ & G & SNV & missense & C80G & \multirow{2}{*}{362} & \multirow{2}{*}{$\begin{array}{l}\text { WNT11, } \\
\text { WNT9A, } \\
\text { WNT9B }\end{array}$} & \multirow{2}{*}{ (none) } \\
\hline & GE2523 & t2180 & mom-2 & V & 8357121 & $\mathrm{~T}$ & C & SNV & missense & C139R & & & \\
\hline \multirow{2}{*}{ W } & GE2497 & t2137 & mre-11 & V & 10735712 & G & A & SNV & missense & H269Y & \multirow{2}{*}{728} & \multirow{2}{*}{ MRE11 } & \multirow{2}{*}{$\begin{array}{l}\text { Ataxia-telangiectasia-like } \\
\text { disorder } 1 \text { [604391] }\end{array}$} \\
\hline & GE2103 & t2092 & mre-11 & V & 10736080 & $A$ & G & SNV & missense & F146S & & & \\
\hline \multirow{2}{*}{ v } & GE2091 & $\mathrm{t} 1772$ & nstp-2 & IV & 6604731 & A & $\mathrm{T}$ & SNV & missense & L277H & \multirow{2}{*}{324} & \multirow{2}{*}{ SLC35B4 } & \multirow{2}{*}{ (none) } \\
\hline & GE2288 & t1835 & nstp-2 & IV & 6605266 & C & $\mathrm{T}$ & SNV & missense & G131R & & & \\
\hline \multirow{2}{*}{$\mathrm{F}$} & GE2391 & t1932 & perm-5 & IV & 5696931 & A & $\mathrm{T}$ & SNV & missense & C454S & \multirow{2}{*}{518} & dnor & lnonol \\
\hline & GE2453 & t1900 & perm-5 & IV & 5698096 & A & G & SNV & missense & S323P & & (none) & (none) \\
\hline gene- & GE2237 & t1614 & pod-1 & III & 13518266 & G & A & SNV & missense & A912V & 1136 & CORO7, & lnon \\
\hline 21 & GE2605 & t1674 & pod-1 & III & 13518357 & G & A & SNV & nonsense & R882* & 1136 & PAM16 & (none) \\
\hline & GE3128 & t2177 & pos-1 & V & 8414544 & G & A & SNV & splice site & - & & ( & (nonot \\
\hline U & GE2101 & t2080 & pos-1 & V & 8414579 & $\mathrm{~T}$ & A & SNV & missense & V145D & 264 & none) & one) \\
\hline 7 & GE2517 & t2175 & rad-50 & V & 12247914 & $\mathrm{~T}$ & A & SNV & nonsense & L350* & 1217 & RAD5, & Nijmegen breakage syndrome- \\
\hline$L^{2}$ & GE2476 & t2147 & rad-50 & V & 12250324 & $\mathrm{~T}$ & A & SNV & missense & I1101N & 1012 & AC116366.3 & order [613078] \\
\hline
\end{tabular}




\begin{tabular}{|c|c|c|c|c|c|c|c|c|c|c|c|c|c|}
\hline Group & Strain & Allele(s) & Gene & Chr. & Position & \multicolumn{2}{|c|}{$\begin{array}{c}\text { Base } \\
\text { Change }\end{array}$} & Mutation & $\begin{array}{l}\text { Mutation } \\
\text { Type }\end{array}$ & $\begin{array}{c}\text { Amino } \\
\text { Acid }^{+} \\
\text {Change }^{\dagger}\end{array}$ & $\begin{array}{l}\text { Protein Size } \\
\text { (Amino Acids) }^{\dagger}\end{array}$ & $\begin{array}{c}\text { Human } \\
\text { Ortholog(s) }\end{array}$ & $\begin{array}{l}\text { Associated OMIM } \\
\text { phenotype(s) }\end{array}$ \\
\hline \multirow{2}{*}{ E } & GE2189 & t1750 & rad-51 & IV & 10282013 & $A$ & $\mathrm{~T}$ & SNV & missense & I384N & \multirow{2}{*}{395} & \multirow{2}{*}{$\begin{array}{l}\text { DMC1, } \\
\text { RAD51, } \\
\text { RAD51B, } \\
\text { RAD51C, } \\
\text { RAD51D }\end{array}$} & \multirow{2}{*}{$\begin{array}{c}\text { Fanconi anemia, } \\
\text { complementation group R, } \\
\text { group O [617244, 613390]; } \\
\text { Mirror movements } 2 \text { [614508]; } \\
\text { Breast-ovarian cancer, familial, } \\
\text { susceptibility to, } 3 \text { [613399] }\end{array}$} \\
\hline & GE2433 & t1885 & rad-51 & IV & 10282328 & $C$ & $\mathrm{~T}$ & SNV & missense & V323I & & & \\
\hline \multirow{2}{*}{$\begin{array}{c}\text { gene- } \\
11\end{array}$} & GE2347 & t1519 & rmd-1 & III & 9759805 & G & A & SNV & missense & G89R & \multirow{2}{*}{226} & \multirow{2}{*}{$\begin{array}{l}\text { RMDN2, } \\
\text { RMDN3 }\end{array}$} & \multirow{2}{*}{ (none) } \\
\hline & GE2219 & t1501 & rmd-1 & III & 9759929 & G & A & SNV & missense & $\mathrm{R} 130 \mathrm{H}$ & & & \\
\hline \multirow{2}{*}{$\begin{array}{c}\text { gene- } \\
18\end{array}$} & GE2211 & t1476 & sas-1 & III & 12710102 & $C$ & $\mathrm{~T}$ & SNV & missense & P419S & \multirow{2}{*}{570} & \multirow{2}{*}{ (none) } & \multirow{2}{*}{ (none) } \\
\hline & GE2343 & t1521 & sas-1 & III & 12710202 & G & $A$ & SNV & missense & G452E & & & \\
\hline \multirow{2}{*}{$f$} & GE2078 & t2033 & sas-5 & V & 11612449 & $C$ & $\mathrm{~T}$ & SNV & missense & R397C & \multirow{2}{*}{404} & \multirow{2}{*}{ (none) } & \multirow{2}{*}{ (none) } \\
\hline & GE2134 & t2079 & sas-5 & V & 11612449 & $C$ & $\mathrm{~T}$ & SNV & missense & R397C & & & \\
\hline \multirow{2}{*}{$P$} & GE2469 & t2173 & spn-4 & V & 6783986 & $A$ & $\mathrm{~T}$ & SNV & nonsense & L259* & \multirow{2}{*}{351} & \multirow{2}{*}{$\begin{array}{l}\text { RBFOX1, } \\
\text { RBFOX2, } \\
\text { RBFOX3 }\end{array}$} & \multirow{2}{*}{ (none) } \\
\hline & GE2317 & t2098 & spn-4 & V & 6784646 & $A$ & $T$ & SNV & missense & V55D & & & \\
\hline \multirow{2}{*}{ g } & GE2386 & t2165 & sqv-4 & V & 10660827 & G & A & SNV & missense & P182L & \multirow{2}{*}{481} & \multirow{2}{*}{ UGDH } & \multirow{2}{*}{$\begin{array}{l}\text { Epileptic encephalopathy, early } \\
\text { infantile, } 84 \text { [618792] }\end{array}$} \\
\hline & GE2059 & t2025 & sqv-4 & V & 10661143 & G & A & SNV & missense & S93L & & & \\
\hline \multirow{3}{*}{$\begin{array}{l}\text { gene- } \\
5\end{array}$} & GE2277 & t1496 & such-1 & III & 11515520 & G & A & SNV & missense & L686F & \multirow{3}{*}{798} & \multirow{3}{*}{ ANAPC5 } & \multirow{3}{*}{ (none) } \\
\hline & GE2277 & t1496 & such-1 & III & 11515883 & G & A & SNV & missense & H565Y & & & \\
\hline & GE2666 & t1693 & such-1 & III & 11515540 & $C$ & $\mathrm{~T}$ & SNV & missense & R679K & & & \\
\hline \multirow{2}{*}{$q$} & GE2827 & t1786 & T22B11.1 & IV & 4692945 & G & A & SNV & nonsense & W35* & \multirow{2}{*}{468} & \multirow{2}{*}{ (none) } & \\
\hline & GE2895 & t1866 & T22B11.1 & IV & 4696017 & G & A & SNV & nonsense & W356* & & & (none) \\
\hline gene- & GE1734 & $\begin{array}{l}\mathrm{t} 1438 \\
\mathrm{t} 1477\end{array}$ & tlk-1 & III & 9707175 & $C$ & $\mathrm{~T}$ & SNV & nonsense & Q412* & 965 & TLK1, TLK2, & Mental retardation, autosomal \\
\hline 12 & GE2613 & t1677 & tlk-1 & III & 9708080 & G & A & SNV & missense & A694T & & TLK2PS1 & dominant $57[618050]$ \\
\hline
\end{tabular}




\begin{tabular}{|c|c|c|c|c|c|c|c|c|c|c|c|c|c|}
\hline Group & Strain & Allele(s) & Gene & Chr. & Position & \multicolumn{2}{|c|}{$\begin{array}{l}\text { Base } \\
\text { Change }\end{array}$} & Mutation & $\begin{array}{l}\text { Mutation } \\
\text { Type }\end{array}$ & $\begin{array}{c}\text { Amino } \\
\text { Acid } \\
\text { Change }^{+}\end{array}$ & $\begin{array}{l}\text { Protein Size } \\
\text { (Amino Acids) }^{\dagger}\end{array}$ & $\begin{array}{c}\text { Human } \\
\text { Ortholog(s) }\end{array}$ & $\begin{array}{l}\text { Associated OMIM } \\
\text { phenotype(s) }\end{array}$ \\
\hline \multirow{2}{*}{$\begin{array}{l}\text { gene- } \\
15\end{array}$} & GE2399 & t1559 & top-3 & III & 11951381 & G & A & SNV & nonsense & Q602* & \multirow{4}{*}{759} & \multirow{4}{*}{ TOP3A } & \multirow{4}{*}{$\begin{array}{l}\text { Progressive external } \\
\text { ophthalmoplegia with } \\
\text { mitochondrial DNA deletions, } \\
\text { autosomal recessive } 5 \\
\text { [618098]; Microcephaly, } \\
\text { growth restriction, and } \\
\text { increased sister chromatid } \\
\text { exchange } 2 \text { [618097] }\end{array}$} \\
\hline & GE2220 & $\mathrm{t} 1516$ & top-3 & III & 11958680 & C & $\mathrm{T}$ & SNV & missense & G59R & & & \\
\hline \multirow{2}{*}{$\begin{array}{l}\text { gene- } \\
35\end{array}$} & GE1735 & t1470 & top-3 & III & 11957525 & C & $\mathrm{T}$ & SNV & nonsense & W114* & & & \\
\hline & GE2958 & $\begin{array}{l}\mathrm{t} 1464 \\
\mathrm{t} 1484\end{array}$ & top-3 & III & 11951669 & C & $\mathrm{T}$ & SNV & missense & G506R & & & \\
\hline \multirow[b]{2}{*}{ L } & GE2512 & t1909 & $\operatorname{trcs}-1$ & IV & 9587541 & C & $\mathrm{T}$ & SNV & missense & E373K & \multirow[b]{2}{*}{428} & \multirow{2}{*}{$\begin{array}{c}\text { AADAC, } \\
\text { AADACL2, } \\
\text { AADACL3, } \\
\text { AADACL4, } \\
\text { NCEH1 }\end{array}$} & \multirow[b]{2}{*}{ (none) } \\
\hline & GE1939 & t1745 & $\operatorname{trcs}-1$ & IV & 9587985 & G & A & SNV & nonsense & Q242* & & & \\
\hline \multirow{2}{*}{ c } & GE2112 & t2037 & unc-112 & V & 14692219 & C & $\mathrm{T}$ & SNV & missense & R669Q & \multirow{2}{*}{720} & \multirow{2}{*}{$\begin{array}{l}\text { FERMT1, } \\
\text { FERMT2, } \\
\text { FERMT3 }\end{array}$} & \multirow{2}{*}{$\begin{array}{c}\text { Kindler syndrome [173650]; } \\
\text { Leukocyte adhesion deficiency, } \\
\text { type III [612840] }\end{array}$} \\
\hline & GE2326 & t2106 & unc-112 & V & 14696546 & C & $\mathrm{T}$ & SNV & splice site & - & & & \\
\hline \multirow{2}{*}{$\begin{array}{l}\text { gene- } \\
27\end{array}$} & GE1722 & t1435 & vps-33.1 & III & 8701605 & C & $\mathrm{T}$ & SNV & nonsense & R159* & \multirow{2}{*}{603} & \multirow{2}{*}{$\begin{array}{c}\text { VPS33A, } \\
\text { VPS33B, } \\
\text { AC048338.1 }\end{array}$} & \multirow{2}{*}{$\begin{array}{c}\text { Mucopolysaccharidosis-plus } \\
\text { syndrome [617303]; } \\
\text { Arthrogryposis, renal } \\
\text { dysfunction [208085] }\end{array}$} \\
\hline & GE2366 & t1561 & vps-33.1 & III & 8702923 & G & A & SNV & nonsense & W536* & & & \\
\hline \multirow{3}{*}{ Q } & GE2292 & $\mathrm{t} 2114$ & vps-39 & V & 14035713 & G & A & SNV & nonsense & Q754* & \multirow{3}{*}{926} & \multirow{3}{*}{ VPS39 } & \multirow{3}{*}{ (none) } \\
\hline & GE1937 & t2189 & vps-39 & V & 14036143 & C & $\mathrm{T}$ & SNV & nonsense & W626* & & & \\
\hline & GE2056 & t2016 & vps-39 & V & 14037839 & G & C & SNV & nonsense & Y122* & & & \\
\hline \multirow[b]{2}{*}{$\mathrm{N}$} & GE2153 & t1773 & wapl-1 & IV & 4444464 & C & $\mathrm{T}$ & SNV & nonsense & W348* & \multirow[b]{2}{*}{748} & \multirow[b]{2}{*}{ WAPL } & \multirow[b]{2}{*}{ (none) } \\
\hline & GE2305 & t1867 & wapl-1 & IV & $\begin{array}{l}4442749- \\
4442872\end{array}$ & - & - & $\begin{array}{l}\text { 122-bp } \\
\text { deletion }\end{array}$ & deletion & - & & & \\
\hline \multirow{3}{*}{$p$} & GE2738 & $\mathrm{t} 1833$ & Y54G2A.73 & IV & 3000662 & A & $\mathrm{T}$ & SNV & nonsense & L341* & \multirow{3}{*}{380} & \multirow{3}{*}{ (none) } & \multirow{3}{*}{ (none) } \\
\hline & GE2387 & t1913 & Y54G2A.73 & IV & 3001767 & G & A & SNV & nonsense & $\mathrm{R} 252^{*}$ & & & \\
\hline & GE2884 & $\mathrm{t} 1755$ & Y54G2A.73 & IV & 3008481 & C & $\mathrm{T}$ & SNV & splice site & - & & & \\
\hline \multirow{2}{*}{$\begin{array}{l}\text { gene- } \\
23\end{array}$} & GE1713 & $\mathrm{t} 1433$ & ZK688.9 & III & 7882477 & C & $\mathrm{T}$ & SNV & nonsense & W135* & 28 & & \\
\hline & GE2621 & t1587 & ZK688.9 & III & 7882717 & C & $\mathrm{T}$ & SNV & splice site & - & 281 & IIPRL & (none) \\
\hline gene- & GE2348 & $\mathrm{t} 1518$ & zyg-8 & III & 12063671 & C & $\mathrm{T}$ & SNV & nonsense & R312* & 802 & DCLK1, & Lissencephaly, X-linked, 1; \\
\hline 14 & GE2362 & t1547 & zyg-8 & III & 12063832 & G & A & SNV & splice site & - & 002 & DCLK3, DCX & heterotopia, X-linked [300067] \\
\hline
\end{tabular}


${ }^{\dagger}$ Amino acid position and size derived from the longest transcript (wormbase.org, version WS275)

${ }^{\ddagger}$ Phenotypes retrieved from omim.org 
627 Table 3. Genes of interest and associated phenotypes

\begin{tabular}{|c|c|c|c|c|c|c|c|}
\hline Strain & Allele & $\begin{array}{l}\text { Gene } \\
\text { Name }\end{array}$ & Protein Function $^{\dagger}$ & $\begin{array}{l}\text { Amino } \\
\text { Acid } \\
\text { Change }^{+}\end{array}$ & RNAi Phenotype ${ }^{\ddagger}$ & Mutant Phenotype & $\begin{array}{l}\text { Embryonic } \\
\text { Osmotic } \\
\text { Integrity } \\
\text { Defect }\end{array}$ \\
\hline GE1936 & $\mathrm{t} 1738$ & \multirow{2}{*}{ atg-7 } & \multirow{2}{*}{$\begin{array}{l}\text { E1 ubiquitin-activating-like } \\
\text { enzyme orthologous to the } \\
\text { autophagic budding yeast } \\
\text { protein Apg7p }\end{array}$} & W311* & \multirow{2}{*}{$\begin{array}{l}\text { growth variant; dauer body morphology variant; pathogen induced } \\
\text { death increased; P granule localization defective; dauer development } \\
\text { variant; protein aggregation variant; shortened life span; transgene } \\
\text { subcellular localization variant; transgene expression variant; necrotic } \\
\text { cell death variant; autophagy variant; antibody staining reduced }\end{array}$} & dead embryos & no \\
\hline GE1958 & $\mathrm{t} 1726$ & & & Q367* & & dead embryos & no \\
\hline GE2627 & $\mathrm{t} 1603$ & \multirow{2}{*}{ bckd-1A } & \multirow{2}{*}{$\begin{array}{l}\text { Predicted mitochondrial } \\
\text { protein with alpha-ketoacid } \\
\text { dehydrogenase activity }\end{array}$} & W150* & \multirow{2}{*}{ shortened life span; small } & dead embryos & yes \\
\hline GE2206 & $\mathrm{t} 1514$ & & & Q161* & & dead embryos & yes \\
\hline GE2840 & t1860 & \multirow{2}{*}{ C34D4.4 } & \multirow{2}{*}{$\begin{array}{l}\text { Predicted to have the } \\
\text { following domain: Golgi } \\
\text { apparatus membrane } \\
\text { protein TVP23-like }\end{array}$} & W131* & \multirow{2}{*}{--} & $\begin{array}{l}\text { unfertilized } \\
\text { oocytes }\end{array}$ & N/A \\
\hline GE2890 & $\mathrm{t} 1821$ & & & W101* & & $\begin{array}{l}\text { unfertilized } \\
\text { oocytes }\end{array}$ & N/A \\
\hline GE2734 & t2029 & \multirow{3}{*}{ C56A3.8 } & \multirow{3}{*}{$\begin{array}{l}\text { Predicted to have 1- } \\
\text { phosphatidylinositol 4- } \\
\text { kinase activity }\end{array}$} & G62E & \multirow{3}{*}{$\begin{array}{l}\text { larval lethal; accumulated germline cell corpses; germ cell compartment } \\
\text { morphology variant; germline nuclear positioning variant; larval arrest; } \\
\text { cell membrane organization biogenesis variant; embryonic lethal; rachis } \\
\text { narrow; apoptosis variant; maternal sterile; reduced brood size }\end{array}$} & $\begin{array}{l}\text { unfertilized } \\
\text { oocytes }\end{array}$ & N/A \\
\hline GE2487 & t2149 & & & P82L & & $\begin{array}{l}\text { unfertilized } \\
\text { oocytes }\end{array}$ & N/A \\
\hline GE2886 & t2055 & & & E243K & & $\begin{array}{l}\text { unfertilized } \\
\text { oocytes }\end{array}$ & N/A \\
\hline GE2122 & t2007 & \multirow{2}{*}{ cept-2 } & \multirow{2}{*}{$\begin{array}{c}\text { Predicted to have } \\
\text { diacylglycerol } \\
\text { cholinephosphotransferase } \\
\text { activity and } \\
\text { ethanolaminephospho- } \\
\text { transferase activity }\end{array}$} & splice site & \multirow{2}{*}{ fat content reduced; embryonic lethal; long } & dead embryos & no \\
\hline GE2047 & t2021 & & & W128* & & $\begin{array}{l}\text { no eggs laid } \\
\text { (dead embryos) } \\
\text { [ts] }\end{array}$ & some \\
\hline GE2275 & $\mathrm{t} 1517$ & \multirow{2}{*}{ cls-2 } & \multirow{2}{*}{$\begin{array}{l}\text { Member of the CLASP } \\
\text { family of microtubule- } \\
\text { binding proteins }\end{array}$} & R102Q & \multirow{2}{*}{$\begin{array}{c}\text { locomotion variant; mitosis variant; univalent meiotic chromosomes; no } \\
\text { polar body formation; chromosome segregation variant karyomeres } \\
\text { early emb; mitotic chromosome segregation variant; mitotic spindle } \\
\text { defective early emb; chromosome segregation variant; embryonic } \\
\text { lethal; meiotic spindle defective; meiotic progression during oogenesis } \\
\text { variant; exploded through vulva; reduced brood size; antibody } \\
\text { subcellular localization variant; meiotic chromosome segregation } \\
\text { variant }\end{array}$} & dead embryos & $\mathrm{N} / \mathrm{T}$ \\
\hline GE2357 & $\mathrm{t} 1527$ & & & G114R & & dead embryos & no \\
\hline GE1938 & $\mathrm{t} 1742$ & \multirow{2}{*}{ cpt-2 } & \multirow{2}{*}{$\begin{array}{l}\text { Carnitine palmitoyl } \\
\text { transferase }\end{array}$} & W194* & \multirow{2}{*}{ embryonic lethal } & dead embryos & no \\
\hline GE2447 & $\mathrm{t} 1879$ & & & Q141* & & dead embryos & no \\
\hline
\end{tabular}




\begin{tabular}{|c|c|c|c|c|c|c|c|}
\hline Strain & Allele & $\begin{array}{l}\text { Gene } \\
\text { Name }\end{array}$ & Protein Function $^{\dagger}$ & $\begin{array}{l}\text { Amino } \\
\text { Acid } \\
\text { Change }^{+}\end{array}$ & RNAi Phenotype ${ }^{\ddagger}$ & Mutant Phenotype & $\begin{array}{l}\text { Embryonic } \\
\text { Osmotic } \\
\text { Integrity } \\
\text { Defect }\end{array}$ \\
\hline GE2407 & t1906 & \multirow{2}{*}{ D2096.12 } & \multirow{2}{*}{--} & L638* & \multirow{2}{*}{ locomotion variant } & dead embryos & some \\
\hline GE2499 & t1877 & & & Q126* & & dead embryos & yes \\
\hline GE2063 & t2042 & \multirow[t]{2}{*}{ dgtr-1 } & \multirow[t]{2}{*}{ Acyl chain transfer enzyme } & G310R & \multirow{2}{*}{$\begin{array}{l}\text { sterile; sick; oocyte number decreased; germline nuclear positioning } \\
\text { variant; oocyte septum formation variant; embryonic lethal; embryo } \\
\text { osmotic integrity defective early emb; oocyte morphology variant; } \\
\text { pachytene region organization variant; reduced brood size; germ cell } \\
\text { compartment expansion variant; oogenesis variant }\end{array}$} & dead embryos & some \\
\hline GE2135 & t2043 & & & splice site & & dead embryos & yes \\
\hline GE2541 & t2035 & \multirow{2}{*}{ dlat-1 } & \multirow{2}{*}{$\begin{array}{l}\text { Predicted to have } \\
\text { dihydrolipoyllysine-residue } \\
\text { acetyltransferase activity }\end{array}$} & P83L & \multirow{2}{*}{$\begin{array}{c}\text { embryonic lethal; slow growth; receptor mediated endocytosis } \\
\text { defective; pattern of transgene expression variant; sterile progeny; } \\
\text { transgene expression increased; general pace of development defective } \\
\text { early emb }\end{array}$} & dead embryos & no \\
\hline GE2335 & t2056 & & & Q419* & & dead embryos & no \\
\hline GE2402 & t1940 & \multirow{2}{*}{ F21D5.1 } & \multirow{2}{*}{$\begin{array}{l}\text { Predicted to have } \\
\text { phosphoacetyl-glucosamine } \\
\text { mutase activity }\end{array}$} & A436V & \multirow{2}{*}{$\begin{array}{l}\text { sterile; germ cell compartment size variant; rachis wide; rachis } \\
\text { morphology variant; accumulated germline cell corpses; germ cell } \\
\text { compartment morphology variant; germline nuclear positioning variant; } \\
\text { embryonic lethal; embryo osmotic integrity defective early emb; } \\
\text { apoptosis variant; reduced brood size; oogenesis variant }\end{array}$} & dead embryos & yes \\
\hline GE2445 & t1935 & & & L539F & & dead embryos & yes \\
\hline GE2881 & $\mathrm{t} 1744$ & \multirow{2}{*}{ F56D5.2 } & \multirow{2}{*}{--} & S107F & \multirow{2}{*}{--} & $\begin{array}{l}\text { unfertilized } \\
\text { oocytes }\end{array}$ & N/A \\
\hline GE2837 & t1791 & & & Q214* & & $\begin{array}{l}\text { unfertilized } \\
\text { oocytes }\end{array}$ & N/A \\
\hline GE2091 & t1772 & \multirow[t]{2}{*}{ nstp-2 } & \multirow{2}{*}{$\begin{array}{l}\text { Predicted to have UDP-N- } \\
\text { acetylglucosamine and } \\
\text { UDP-xylose transmembrane } \\
\text { transporter activity }\end{array}$} & L277H & \multirow{2}{*}{$\begin{array}{l}\text { lysosome-related organelle morphology variant; transgene subcellular } \\
\text { localization variant; RAB-11 recycling endosome localization variant; } \\
\text { RAB-11 recycling endosome morphology variant }\end{array}$} & dead embryos & no \\
\hline GE2288 & $\mathrm{t} 1835$ & & & G131R & & dead embryos & no \\
\hline GE2391 & t1932 & \multirow{2}{*}{ perm-5 } & \multirow{2}{*}{$\begin{array}{l}\text { Predicted to have lipid } \\
\text { binding activity }\end{array}$} & C454S & \multirow{2}{*}{$\begin{array}{l}\text { sterile; apoptosis reduced; oocytes lack nucleus; oocyte number } \\
\text { decreased; germ cell compartment morphology variant; germline } \\
\text { nuclear positioning variant; germ cell compartment anucleate; oocyte } \\
\text { septum formation variant; cell membrane organization biogenesis } \\
\text { variant; embryonic lethal; embryo osmotic integrity defective early } \\
\text { emb; oogenesis variant; diplotene region organization variant }\end{array}$} & dead embryos & yes \\
\hline GE2453 & t1900 & & & S323P & & dead embryos & yes \\
\hline GE2827 & t1786 & \multirow{2}{*}{ T22B11.1 } & \multirow{2}{*}{--} & W35* & \multirow{2}{*}{--} & $\begin{array}{l}\text { unfertilized } \\
\text { oocytes [ts] }\end{array}$ & N/A \\
\hline GE2895 & t1866 & & & W356* & & $\begin{array}{l}\text { unfertilized } \\
\text { oocytes [ts] }\end{array}$ & N/A \\
\hline
\end{tabular}




\begin{tabular}{|c|c|c|c|c|c|c|c|}
\hline Strain & Allele & $\begin{array}{l}\text { Gene } \\
\text { Name }\end{array}$ & Protein Function $^{\dagger}$ & $\begin{array}{c}\text { Amino } \\
\text { Acid }^{+} \\
\text {Change }^{+}\end{array}$ & RNAi Phenotype ${ }^{\ddagger}$ & Mutant Phenotype & $\begin{array}{c}\text { Embryonic } \\
\text { Osmotic } \\
\text { Integrity } \\
\text { Defect }\end{array}$ \\
\hline GE2399 & t1559 & \multirow{2}{*}{ top-3 } & \multirow{2}{*}{$\begin{array}{c}\text { Exhibits DNA topoisomerase } \\
\text { type I (single strand cut, } \\
\text { ATP-independent) activity }\end{array}$} & G59R & \multirow{2}{*}{$\begin{array}{l}\text { chromosome morphology variant; hermaphrodite germline proliferation } \\
\text { variant; antibody staining increased; somatic gonad development } \\
\text { variant; gonad degenerate; chromosome instability; germ cell mitosis } \\
\text { variant; gonad arm morphology variant; meiosis variant; oocyte } \\
\text { morphology variant; nuclear appearance variant; fewer germ cells; } \\
\text { oogenesis variant }\end{array}$} & dead embryos & no \\
\hline GE2220 & t1516 & & & Q602* & & dead embryos & no \\
\hline GE2512 & t1909 & \multirow{2}{*}{$\operatorname{trcs}-1$} & \multirow{2}{*}{$\begin{array}{c}\text { Putative arylacetamide } \\
\text { deacetylase and microsomal } \\
\text { lipase }\end{array}$} & E373K & \multirow{2}{*}{$\begin{array}{l}\text { apoptosis reduced; diplotene absent during oogenesis; oocyte number } \\
\text { decreased; embryo osmotic integrity defective early emb; rachis } \\
\text { narrow; chromosome condensation variant; pachytene region } \\
\text { organization variant; membrane trafficking variant; pachytene } \\
\text { progression during oogenesis variant; apoptosis fails to occur; egg laying } \\
\text { variant; germ cell compartment expansion absent; embryonic lethal; } \\
\text { cell membrane organization biogenesis variant; no oocytes; germ cell } \\
\text { compartment expansion variant }\end{array}$} & $\begin{array}{c}\text { dead embryos } \\
\text { [leaky ts] }\end{array}$ & yes \\
\hline GE1939 & $\mathrm{t} 1745$ & & & Q242* & & $\begin{array}{c}\text { no eggs laid } \\
\text { (dead embryos) } \\
\text { [ts] }\end{array}$ & yes \\
\hline GE2884 & t1755 & \multirow{3}{*}{ Y54G2A.73 } & \multirow{3}{*}{--} & splice site & \multirow{3}{*}{--} & $\begin{array}{c}\text { unfertilized } \\
\text { oocytes }\end{array}$ & $\mathrm{N} / \mathrm{A}$ \\
\hline GE2387 & t1913 & & & $\mathrm{R} 252^{*}$ & & $\begin{array}{c}\text { unfertilized } \\
\text { oocytes }\end{array}$ & $\mathrm{N} / \mathrm{A}$ \\
\hline GE2738 & t1833 & & & L341* & & $\begin{array}{c}\text { unfertilized } \\
\text { oocytes }\end{array}$ & N/A \\
\hline GE1713 & t1433 & \multirow{2}{*}{ ZK688.9 } & \multirow{2}{*}{$\begin{array}{l}\text { Predicted to have the } \\
\text { following domain: TIP41-like } \\
\text { protein (TOR signaling } \\
\text { pathway regulator) }\end{array}$} & W135* & \multirow{2}{*}{ egg laying variant; locomotion variant } & dead embryos & no \\
\hline GE2621 & t1587 & & & splice site & & dead embryos & no \\
\hline
\end{tabular}

$[\mathrm{ts}]=$ temperature sensitive

$\mathrm{N} / \mathrm{A}=$ not applicable

$\mathrm{N} / \mathrm{T}=$ not tested

$--=$ no information available
${ }^{\dagger}$ From WormBase (WS275; wormbase.org); amino acid position derived from the longest transcript

${ }^{\ddagger}$ Phenotypes retrieved from GExplore (genome.sfu.ca/gexplore) 
631 Table 4. Complementation tests for conflicting groups

\begin{tabular}{|c|c|c|c|c|c|c|}
\hline $\begin{array}{c}\text { Original } \\
\text { Complementation } \\
\text { Group }\end{array}$ & Strain & Allele & $\begin{array}{l}\text { Preliminary } \\
\text { Gene } \\
\text { Candidate }\end{array}$ & Mapped Under & Complement Test Results & Final Gene Assignment \\
\hline gene-28 & GE1742 & t1461 & $b c k d-1 A$ & None of tested deficiencies & Fails to complement: GE2206, GE2627 & $b c k d-1 A$ \\
\hline \multirow{2}{*}{ gene-17 } & GE2627 & t1603 & \multirow{2}{*}{$b c k d-1 A$} & $t D f 5$ & Fails to complement: GE2206, GE1742 & \multirow{2}{*}{$b c k d-1 A$} \\
\hline & GE2206 & t1514 & & tDf5 & Fails to complement: GE2627, GE1742 & \\
\hline \multirow{2}{*}{ gene-15 } & GE2220 & t1516 & \multirow{2}{*}{ top-3 } & tDf5 & $\begin{array}{c}\text { Fails to complement: GE2399, GE1735 } \\
\text { Complements: GE2278 }\end{array}$ & \multirow{2}{*}{ top-3 } \\
\hline & GE2399 & t1559 & & tDf5 & Fails to complement: GE2220 & \\
\hline gene-34 & GE2278 & t1502 & top-3 & None of tested deficiencies & $\begin{array}{l}\text { Fails to complement: GE1735 } \\
\text { Complements: GE2220 }\end{array}$ & unknown gene \\
\hline gene-35 & GE1735 & t1470 & top-3 & None of tested deficiencies & Fails to complement: GE2278, GE2220 & $\begin{array}{l}\text { double mutant: top-3 + } \\
\text { unknown gene }\end{array}$ \\
\hline
\end{tabular}

$N / T=$ not tested 
bioRxiv preprint doi: https://doi.org/10.1101/2021.06.16.448744; this version posted June 19, 2021. The copyright holder for this preprint (which was not certified by peer review) is the author/funder, who has granted bioRxiv a license to display the preprint in perpetuity. It is made available under aCC-BY 4.0 International license.

633 Table 5. Putative male fertility genes

\begin{tabular}{|c|c|c|c|c|}
\hline Strain & Allele & Gene & Observed Mutant Phenotype & Successful WT Male Rescue \\
\hline GE2627 & t1603 & \multirow{2}{*}{ bckd-1A } & dead embryos & yes \\
\hline GE2206 & $\mathrm{t} 1514$ & & dead embryos & yes \\
\hline GE2840 & t1860 & \multirow{2}{*}{ C34D4.4 } & unfertilized oocytes & yes \\
\hline GE2890 & $\mathrm{t} 1821$ & & unfertilized oocytes & yes \\
\hline GE2734 & t2029 & \multirow{3}{*}{ С56А3.8 } & unfertilized oocytes & yes \\
\hline GE2487 & t2149 & & unfertilized oocytes & yes \\
\hline GE2886 & t2055 & & unfertilized oocytes & yes \\
\hline GE2881 & $\mathrm{t} 1744$ & \multirow{2}{*}{ F56D5.2 } & unfertilized oocytes & no \\
\hline GE2837 & $\mathrm{t} 1791$ & & unfertilized oocytes & yes \\
\hline GE2091 & $\mathrm{t} 1772$ & \multirow{2}{*}{ nstp-2 } & dead embryos & no \\
\hline GE2288 & t1835 & & dead embryos & yes \\
\hline GE2827 & $\mathrm{t} 1786$ & \multirow{2}{*}{ T22B11.1 } & unfertilized oocytes [ts] & yes \\
\hline GE2895 & t1866 & & unfertilized oocytes [ts] & yes \\
\hline GE2884 & $\mathrm{t} 1755$ & \multirow{3}{*}{ Y54G2A.73 } & unfertilized oocytes & yes \\
\hline GE2387 & t1913 & & unfertilized oocytes & yes \\
\hline GE2738 & $\mathrm{t} 1833$ & & unfertilized oocytes & yes \\
\hline
\end{tabular}

634

[ts] = temperature sensitive 
FIGURE LEGENDS

637 Figure 1 Schematic of gene assignments and deficiency mapping. Genes and deficiencies are

638 shown with their relative positions on chromosomes III, IV, and V. Approximate boundaries of

639 each deficiency were determined by the coordinates of the closest gene known to lie outside of

640 the deletion, when possible (indicated by a faded edge). If no such genes with physical

641 coordinates are known, the outermost gene known to lie inside the deletion was used as the

642 boundary (indicated by a sharp edge). Gene names are coloured according to the deficiency

643 under which the alleles were mapped. Genes names assigned to alleles that did not map under

644 any of the tested deficiencies are highlighted in grey. top-3 and $b c k d-1 A$ on chromosome III are

645 represented by multiple complementation groups with conflicting results from deficiency

646 mapping.

647

648 Figure 2 Biological Process GO terms overrepresented in the set of 58 identified essential genes.

649 Bar length represents the number of genes in the set associated with each GO term.

650 Overrepresentation was analyzed using PANTHER version 16.0 (Thomas et al. 2003) and p-values

651 were adjusted with the Bonferroni multiple testing correction. Results were filtered to include

652 terms with adjusted $p<0.05$ and edited to exclude redundant terms.

653

654 Figure 3 Embryonic arrest visualized with DIC microscopy for select maternal-effect lethal

655 mutants. Eggs were dissected from homozygous mutants and imaged immediately (A) or

656 incubated in distilled water overnight before imaging ( $B, C$, and D). (A) Eggs dissected from dgtr- 
bioRxiv preprint doi: https://doi.org/10.1101/2021.06.16 448744; this version posted June 19, 2021. The copyright holder for this preprint (which was not certified by peer review) is the author/funder, who has granted bioRxiv a license to display the preprint in perpetuity. It is made available under aCC-BY 4.0 International license.

657 1(t2043) homozygotes exhibit signs of an osmotic integrity defect, by filling the eggshell

658 completely. (B) dlat-1(t2035) embryos exhibit early embryonic arrest, with most embryos

659 consisting of four cells or less. (C) ZK688.9(t1433) embryos arrest with approximately 100 cells.

660 (D) Terminal embryos of nstp-2(t1835) have a lumpy body wall morphology and constricted

661 nose; most animals were moving inside the eggshell but did not hatch. All scale bars represent

$66210 \mu \mathrm{m}$.

663 

search tool. J. Mol. Biol. 215: 403-410.

668 Au, V., E. Li-Leger, G. Raymant, S. Flibotte, G. Chen et al., 2019 CRISPR/Cas9 methodology for the

669 generation of knockout deletions in Caenorhabditis elegans. G3: Genes, Genomes, Genet. 9: 135-

670144.

671 Ausländer, S., D. Ausländer and M. Fussenegger, 2017 Synthetic biology-the synthesis of

672 biology. Angew. Chem. Int. Ed. 56: 6396-6419.

673 Bao, Z., J. I. Murray, T. Boyle, S. L. Ooi, M. J. Sandel et al., 2006 Automated cell lineage tracing in

674 Caenorhabditis elegans. Proc. Natl. Acad. Sci. U.S.A. 103: 2707-2712.

675 Benenati, G., S. Penkov, T. Müller-Reichert, E. V. Entchev and T. V. Kurzchalia, 2009 Two

676 cytochrome P450s in Caenorhabditis elegans are essential for the organization of eggshell,

677 correct execution of meiosis and the polarization of embryo. Mech. Dev. 126: 382-393.

678 Bischoff, M., and R. Schnabel, 2006 A posterior centre establishes and maintains polarity of the

679 Caenorhabditis elegans embryo by a Wnt-dependent relay mechanism. PLoS Biol. 4: e396.

680 Blumenstiel, J. P., A. C. Noll, J. A. Griffiths, A. G. Perera, K. N. Walton et al., 2009 Identification of

681 EMS-induced mutations in Drosophila melanogaster by whole-genome sequencing.

682 Genetics 182: 25-32.

683 Boeck, M. E., C. Huynh, L. Gevirtzman, O. A. Thompson, G. Wang et al., 2016 The time-resolved 684 transcriptome of C. elegans. Genome Res. 26: 1441-1450. 
685 Bradley, A., K. Anastassiadis, A. Ayadi, J. F. Battey, C. Bell et al., 2012 The mammalian gene

686 function resource: The international knockout mouse consortium. Mammalian genome 23: 580-

687586.

688 Brauchle, M., K. Baumer and P. Gönczy, 2003 Differential activation of the DNA replication

689 checkpoint contributes to asynchrony of cell division in C. elegans embryos. Curr. Biol. 13: 819-

690827.

691 Brenner, S., 1974 The genetics of Caenorhabditis elegans. Genetics 77: 71-94.

692 Bürglin, T. R., E. Lobos and M. L. Blaxter, 1998 Caenorhabditis elegans as a model for parasitic

693 nematodes. Int. J. Parasitol. 28: 395-411.

694 C. elegans Deletion Mutant Consortium, 2012 Large-scale screening for targeted knockouts in

695 the Caenorhabditis elegans genome. G3: Genes, Genomes, Genet. 2: 1415-1425.

696 Carvalho, A., S. K. Olson, E. Gutierrez, K. Zhang, L. B. Noble et al., 2011 Acute drug treatment in

697 the early C. elegans embryo. Plos one 6: e24656.

698 Clark, D. V., T. M. Rogalski, L. M. Donati and D. L. Baillie, 1988 The unc-22 (IV) region of

699 Caenorhabditis elegans: Genetic analysis of lethal mutations. Genetics 119: 345-353.

700 Cockell, M. M., K. Baumer and P. Gönczy, 2004 Lis-1 is required for dynein-dependent cell

701 division processes in C. elegans embryos. J. Cell. Sci. 117: 4571-4582.

702 Culetto, E., and D. B. Sattelle, 2000 A role for Caenorhabditis elegans in understanding the

703 function and interactions of human disease genes. Hum. Mol. Genet. 9: 869-877. 
704 del Castillo-Olivares, A., M. Kulkarni and H. E. Smith, 2009 Regulation of sperm gene expression

705 by the GATA factor ELT-1. Dev. Biol. 333: 397-408.

706 Delattre, M., S. Leidel, K. Wani, K. Baumer, J. Bamat et al., 2004 Centriolar SAS-5 is required for

707 centrosome duplication in C. elegans. Nat. Cell Biol. 6: 656-664.

708 Denver, D. R., K. Morris, M. Lynch and W. K. Thomas, 2004 High mutation rate and

709 predominance of insertions in the Caenorhabditis elegans nuclear genome. Nature 430: 679-682.

710 Dickerson, J. E., A. Zhu, D. L. Robertson and K. E. Hentges, 2011 Defining the role of essential

711 genes in human disease. PloS one 6: e27368.

712 Doitsidou, M., R. J. Poole, S. Sarin, H. Bigelow and O. Hobert, 2010 C. elegans mutant

713 identification with a one-step whole-genome-sequencing and SNP mapping strategy. PloS

714 one 5: e15435.

715 Doyle, M. A., R. B. Gasser, B. J. Woodcroft, R. S. Hall and S. A. Ralph, 2010 Drug target prediction

716 and prioritization: Using orthology to predict essentiality in parasite genomes. BMC

717 Genomics 11: 222.

718 Feichtinger, R. E., 1995 Quantitative Analysis of Maternal Gene Functions of Caenorhabditis

719 Elegans. Ph.D. Thesis, University of Vienna, Austria.

720 Fire, A., S. Xu, M. K. Montgomery, S. A. Kostas, S. E. Driver et al., 1998 Potent and specific genetic

721 interference by double-stranded RNA in Caenorhabditis elegans. Nature 391: 806-811.

722 Flibotte, S., M. L. Edgley, I. Chaudhry, J. Taylor, S. E. Neil et al., 2010 Whole-genome profiling of

723 mutagenesis in Caenorhabditis elegans. Genetics 185: 431-441. 
724 Fraser, A. G., R. S. Kamath, P. Zipperlen, M. Martinez-Campos, M. Sohrmann et al., 2000

725 Functional genomic analysis of C. elegans chromosome I by systematic RNA interference.

$726 \quad$ Nature 408: 325-330.

727 Georgi, B., B. F. Voight and M. Bućan, 2013 From mouse to human: Evolutionary genomics

728 analysis of human orthologs of essential genes. PLoS genet. 9: e1003484.

729 Gerstein, M. B., J. Rozowsky, K. Yan, D. Wang, C. Cheng et al., 2014 Comparative analysis of the

730 transcriptome across distant species.

731 512: 445-448.

732 Gerstein, M. B., Z. J. Lu, E. L. Van Nostrand, C. Cheng, B. I. Arshinoff et al., 2010 Integrative

733 analysis of the Caenorhabditis elegans genome by the modENCODE project. Science 330: 1775-

7341787.

735 Giaever, G., A. M. Chu, L. Ni, C. Connelly, L. Riles et al., 2002 Functional profiling of the

736 Saccharomyces cerevisiae genome. Nature 418: 387-391.

737 Gönczy, P., H. Schnabel, T. Kaletta, A. D. Amores, T. Hyman et al., 1999 Dissection of cell division

738 processes in the one cell stage Caenorhabditis elegans embryo by mutational analysis. J. Cell

739 Biol. 144: 927-946.

740 Gönczy, P., J. Bellanger, M. Kirkham, A. Pozniakowski, K. Baumer et al., 2001 Zyg-8, a gene

741 required for spindle positioning in C. elegans, encodes a doublecortin-related kinase that

742 promotes microtubule assembly. Dev. Cell. 1: 363-375. 
743 Gönczy, P., C. Echeverri, K. Oegema, A. Coulson, S. J. Jones et al., 2000 Functional genomic

744 analysis of cell division in C. elegans using RNAi of genes on chromosome III. Nature 408: 331-

745336.

746 Goodwin, S., J. D. McPherson and W. R. McCombie, 2016 Coming of age: Ten years of next-

747 generation sequencing technologies. Nat. Rev. Genet. 17: 333.

748 Green, R. A., H. Kao, A. Audhya, S. Arur, J. R. Mayers et al., 2011 A high-resolution C. elegans

749 essential gene network based on phenotypic profiling of a complex tissue. Cell 145: 470-482.

750 Hashmi, S., W. Tawe and S. Lustigman, 2001 Caenorhabditis elegans and the study of gene

751 function in parasites. Trends Parasitol. 17: 387-393.

752 Herman, R. K., 1978 Crossover suppressors and balanced recessive lethals in Caenorhabditis

753 elegans. Genetics 88: 49-65.

754 Hillier, L. W., V. Reinke, P. Green, M. Hirst, M. A. Marra et al., 2009 Massively parallel sequencing

755 of the polyadenylated transcriptome of C. elegans. Genome Res. 19: 657-666.

756 Hillier, L. W., G. T. Marth, A. R. Quinlan, D. Dooling, G. Fewell et al., 2008 Whole-genome

757 sequencing and variant discovery in C. elegans. Nat. Methods 5: 183.

758 Hotez, P. J., P. J. Brindley, J. M. Bethony, C. H. King, E. J. Pearce et al., 2008 Helminth infections:

759 The great neglected tropical diseases. J. Clin. Invest. 118: 1311-1321.

760 Howell, A. M., S. G. Gilmour, R. A. Mancebo and A. M. Rose, 1987 Genetic analysis of a large

761 autosomal region in Caenorhabditis elegans by the use of a free duplication. Genetics

762 Research 49: 207-213. 
763 Howell, A. M., and A. M. Rose, 1990 Essential genes in the hDf6 region of chromosome I in

764 Caenorhabditis elegans. Genetics 126: 583-592.

765 Hughes, T. R., 2002 Yeast and drug discovery. Funct. Integr. Genomics 2: 199-211.

766 Hutter, H., and J. Suh, 2016 GExplore 1.4: An expanded web interface for queries on

767 Caenorhabditis elegans protein and gene function. Worm 5: e1234659.

768 Hutter, H., M. Ng and N. Chen, 2009 GExplore: A web server for integrated queries of protein

769 domains, gene expression and mutant phenotypes. BMC Genomics 10: 529.

770 Jabbar, A., Z. Iqbal, D. Kerboeuf, G. Muhammad, M. N. Khan et al., 2006 Anthelmintic resistance:

771 The state of play revisited. Life Sci. 79: 2413-2431.

772 Jaramillo-Lambert, A., A. S. Fuchsman, A. S. Fabritius, H. E. Smith and A. Golden, 2015 Rapid and

773 efficient identification of Caenorhabditis elegans legacy mutations using Hawaiian SNP-based

774 mapping and whole-genome sequencing. G3: Genes, Genomes, Genet. 5: 1007-1019.

775 Johnsen, R. C., and D. L. Baillie, 1997 Mutation, pp. 79-95 in C. Elegans II, edited by Riddle, D.L.,

776 Blumenthal, T., Meyer, B.J., Priess, J.R. Cold Spring Harbor Laboratory Press, Cold Spring Harbor

777 (NY).

778 Johnsen, R. C., and D. L. Baillie, 1991 Genetic analysis of a major segment [LGV (left)] of the

779 genome of Caenorhabditis elegans. Genetics 129: 735-752.

780 Johnsen, R. C., and D. L. Baillie, 1988 Formaldehyde mutagenesis of the eT1 balanced region in

781 Caenorhabditis elegans: Dose-response curve and the analysis of mutational events. Mutat.

782 Res. 201: 137-147. 
783 Johnston, W. L., A. Krizus and J. W. Dennis, 2006 The eggshell is required for meiotic fidelity,

784 polar-body extrusion and polarization of the C. elegans embryo. BMC biology 4: 35.

785 Jordan, I. K., I. B. Rogozin, Y. I. Wolf and E. V. Koonin, 2002 Essential genes are more

786 evolutionarily conserved than are nonessential genes in bacteria. Genome Res. 12: 962-968.

787 Kadandale, P., I. Chatterjee and A. Singson, 2009 Germline transformation of Caenorhabditis

788 elegans by injection, pp. 123-133 in Microinjection. Springer.

789 Kaitna, S., H. Schnabel, R. Schnabel, A. A. Hyman and M. Glotzer, 2002 A ubiquitin C-terminal

790 hydrolase is required to maintain osmotic balance and execute actin-dependent processes in the

791 early C. elegans embryo. J. Cell. Sci. 115: 2293-2302.

792 Kamath, R. S., A. G. Fraser, Y. Dong, G. Poulin, R. Durbin et al., 2003 Systematic functional

793 analysis of the Caenorhabditis elegans genome using RNAi. Nature 421: 231-237.

794 Kemphues, K. J., M. Kusch and N. Wolf, 1988 Maternal-effect lethal mutations on linkage group II

795 of Caenorhabditis elegans. Genetics 120: 977-986.

796 Kim, W., R. S. Underwood, I. Greenwald and D. D. Shaye, 2018 OrthoList 2: A new comparative

797 genomic analysis of human and Caenorhabditis elegans genes. Genetics 210: 445-461.

798 Kniazeva, M., Q. T. Crawford, M. Seiber, C. Wang and M. Han, 2004 Monomethyl branched-chain

799 fatty acids play an essential role in Caenorhabditis elegans development. PLoS biology 2: e257.

800 Kumar, S., K. Chaudhary, J. M. Foster, J. F. Novelli, Y. Zhang et al., 2007 Mining predicted

801 essential genes of Brugia malayi for nematode drug targets. PloS one 2: e1189. 
802 Li, H., and R. Durbin, 2009 Fast and accurate short read alignment with Burrows-Wheeler

803 transform. Bioinformatics 25: 1754-1760.

804 Li, H., B. Handsaker, A. Wysoker, T. Fennell, J. Ruan et al., 2009 The sequence alignment/map

805 format and SAMtools. Bioinformatics 25: 2078-2079.

806 Li, Z., F. J. Vizeacoumar, S. Bahr, J. Li, J. Warringer et al., 2011 Systematic exploration of essential

807 yeast gene function with temperature-sensitive mutants. Nat. Biotechnol. 29: 361.

808 Ma, X., Y. Zhu, C. Li, P. Xue, Y. Zhao et al., 2014 Characterisation of Caenorhabditis elegans sperm

809 transcriptome and proteome. BMC Genomics 15: 168.

810 McKim, K. S., M. F. Heschl, R. E. Rosenbluth and D. L. Baillie, 1988 Genetic organization of the

811 unc-60 region in Caenorhabditis elegans. Genetics 118: 49-59.

812 McKim, K. S., T. Starr and A. M. Rose, 1992 Genetic and molecular analysis of the dpy-14 region

813 in Caenorhabditis elegans. Mol. Gen. Genet. 233: 241-251.

814 Mello, C. C., J. M. Kramer, D. Stinchcomb and V. Ambros, 1991 Efficient gene transfer in C.

815 elegans: Extrachromosomal maintenance and integration of transforming sequences. EMBO

816 J. 10: 3959-3970.

817 Meneely, P. M., and R. K. Herman, 1979 Lethals, steriles and deficiencies in a region of the X

818 chromosome of Caenorhabditis elegans. Genetics 92: 99-115.

819 Metzker, M. L., 2010 Sequencing technologies - the next generation. Nat. Rev. Genet. 11: 31-46. 
820 Nicol, J. M., S. J. Turner, D. L. Coyne, L. Den Nijs, S. Hockland et al., 2011 Current nematode

821 threats to world agriculture, pp. 21-43 in Genomics and Molecular Genetics of Plant-Nematode

822 Interactions. Springer.

823 Nieto, C., J. Almendinger, S. Gysi, E. Gómez-Orte, A. Kaech et al., 2010 Ccz-1 mediates the

824 digestion of apoptotic corpses in C. elegans. J. Cell. Sci. 123: 2001-2007.

825 Nordström, K. J., M. C. Albani, G. V. James, C. Gutjahr, B. Hartwig et al., 2013 Mutation

826 identification by direct comparison of whole-genome sequencing data from mutant and wild-

827 type individuals using k-mers. Nat. Biotechnol. 31: 325.

828 Norris, A. D., H. Kim, M. P. Colaiacovo and J. A. Calarco, 2015 Efficient genome editing in

829 Caenorhabditis elegans with a toolkit of dual-marker selection cassettes. Genetics 201: 449-58.

830 Olson, S. K., G. Greenan, A. Desai, T. Müller-Reichert and K. Oegema, 2012 Hierarchical assembly

831 of the eggshell and permeability barrier in C. elegans. J. Cell Biol. 198: 731-748.

832 Packer, J. S., Q. Zhu, C. Huynh, P. Sivaramakrishnan, E. Preston et al., 2019 A lineage-resolved

833 molecular atlas of C. elegans embryogenesis at single-cell resolution. Science 365: eaax1971.

834 Qin, Z., R. Johnsen, S. Yu, J. S. Chu, D. L. Baillie et al., 2018 Genomic identification and functional

835 characterization of essential genes in Caenorhabditis elegans. G3: Genes, Genomes,

836 Genet. 8: 981-997.

837 Rahman, M. M., S. Rosu, D. Joseph-Strauss and O. Cohen-Fix, 2014 Down-regulation of

838 tricarboxylic acid (TCA) cycle genes blocks progression through the first mitotic division in

839 Caenorhabditis elegans embryos. Proc. Natl. Acad. Sci. U.S.A. 111: 2602-2607. 
840 Rappleye, C. A., A. Tagawa, N. Le Bot, J. Ahringer and R. V. Aroian, 2003 Involvement of fatty acid

841 pathways and cortical interaction of the pronuclear complex in Caenorhabditis elegans

842 embryonic polarity. BMC developmental biology 3: 8.

843 Rappleye, C. A., A. R. Paredez, C. W. Smith, K. L. McDonald and R. V. Aroian, 1999 The coronin-

844 like protein POD-1 is required for anterior-posterior axis formation and cellular architecture in

845 the nematode Caenorhabditis elegans. Genes Dev. 13: 2838-2851.

846 Reinke, V., I. San Gil, S. Ward and K. Kazmer, 2004 Genome-wide germline-enriched and sex-

847 biased expression profiles in Caenorhabditis elegans. Development 131: 311-323.

848 Rogalski, T. M., D. G. Moerman and D. L. Baillie, 1982 Essential genes and deficiencies in the unc-

84922 IV region of Caenorhabditis elegans. Genetics 102: 725-736.

850 Sarin, S., S. Prabhu, M. M. O'meara, I. Pe'er and O. Hobert, 2008 Caenorhabditis elegans mutant

851 allele identification by whole-genome sequencing. Nat. Methods 5: 865-867.

852 Schnabel, R., H. Hutter, D. Moerman and H. Schnabel, 1997 Assessing normal embryogenesis in

853 Caenorhabditis elegans using a 4D microscope: Variability of development and regional

854 specification. Dev. Biol. 184: 234-265.

855 Schneeberger, K., and D. Weigel, 2011 Fast-forward genetics enabled by new sequencing

856 technologies. Trends Plant Sci. 16: 282-288.

857 Schneeberger, K., S. Ossowski, C. Lanz, T. Juul, A. H. Petersen et al., 2009 SHOREmap:

858 Simultaneous mapping and mutation identification by deep sequencing. Nat. Methods 6: 550-

859551. 
860 Shi, J., E. Wang, J. P. Milazzo, Z. Wang, J. B. Kinney et al., 2015 Discovery of cancer drug targets

861 by CRISPR-Cas9 screening of protein domains. Nat. Biotechnol. 33: 661-667.

862 Silverman, G. A., C. J. Luke, S. R. Bhatia, O. S. Long, A. C. Vetica et al., 2009 Modeling molecular

863 and cellular aspects of human disease using the nematode Caenorhabditis elegans. Pediatr.

864 Res. 65: 10-18.

865 Smith, D. R., A. R. Quinlan, H. E. Peckham, K. Makowsky, W. Tao et al., 2008 Rapid whole-genome

866 mutational profiling using next-generation sequencing technologies. Genome Res. 18: 1638-

8671642.

868 Smith, H. E., A. S. Fabritius, A. Jaramillo-Lambert and A. Golden, 2016 Mapping challenging

869 mutations by whole-genome sequencing. G3: Genes, Genomes, Genet. 6: 1297-1304.

870 Sonneville, R., and P. Gönczy, 2004 Zyg-11 and cul-2 regulate progression through meiosis II and

871 polarity establishment in C. elegans. Development 131: 3527-3543.

872 Sönnichsen, B., L. B. Koski, A. Walsh, P. Marschall, B. Neumann et al., 2005 Full-genome RNAi

873 profiling of early embryogenesis in Caenorhabditis elegans. Nature 434: 462-469.

874 Srivatsan, A., Y. Han, J. Peng, A. K. Tehranchi, R. Gibbs et al., 2008 High-precision, whole-genome

875 sequencing of laboratory strains facilitates genetic studies. PLoS Genet. 4: e1000139.

876 Stein, K. K., and A. Golden, 2018 The C. elegans eggshell in WormBook: The Online Review of C.

877 Elegans Biology. The C. elegans Research Community. 
878 Stewart, H. I., N. J. O'Neil, D. L. Janke, N. W. Franz, H. M. Chamberlin et al., 1998 Lethal mutations

879 defining 112 complementation groups in a $4.5 \mathrm{mb}$ sequenced region of Caenorhabditis elegans

880 chromosome III. MGG 260: 280-288.

881 The C. elegans Sequencing Consortium, 1998 Genome sequence of the nematode C. elegans: A

882 platform for investigating biology. Science 2012-2018.

883 Thomas, C., P. DeVries, J. Hardin and J. White, 1996 Four-dimensional imaging: Computer

884 visualization of 3D movements in living specimens. Science 273: 603-607.

885 Thomas, P. D., M. J. Campbell, A. Kejariwal, H. Mi, B. Karlak et al., 2003 PANTHER: A library of

886 protein families and subfamilies indexed by function. Genome Res. 13: 2129-2141.

887 Thompson, O., M. Edgley, P. Strasbourger, S. Flibotte, B. Ewing et al., 2013 The million mutation

888 project: A new approach to genetics in Caenorhabditis elegans. Genome Res. 23: 1749-1762.

889 Tintori, S. C., E. O. Nishimura, P. Golden, J. D. Lieb and B. Goldstein, 2016 A transcriptional

890 lineage of the early C. elegans embryo. Dev. Cell 38: 430-444.

891 Varshney, G. K., J. Lu, D. E. Gildea, H. Huang, W. Pei et al., 2013 A large-scale zebrafish gene

892 knockout resource for the genome-wide study of gene function. Genome Res. 23: 727-735.

893 Vatcher, G. P., C. M. Thacker, T. Kaletta, H. Schnabel, R. Schnabel et al., 1998 Serine

894 hydroxymethyltransferase is maternally essential in Caenorhabditis elegans. J. Biol.

895 Chem. 273: 6066-6073.

896 Vyas, V. K., M. I. Barrasa and G. R. Fink, 2015 A Candida albicans CRISPR system permits genetic

897 engineering of essential genes and gene families. Sci. Adv. 1: e1500248. 
898 Wang, S., S. D. Ochoa, R. N. Khaliullin, A. Gerson-Gurwitz, J. M. Hendel et al., 2019 A high-content

899 imaging approach to profile C. elegans embryonic development. Development 146: dev174029.

900 Winzeler, E. A., D. D. Shoemaker, A. Astromoff, H. Liang, K. Anderson et al., 1999 Functional

901 characterization of the S. cerevisiae genome by gene deletion and parallel analysis.

902 Science 285: 901-906.

903 Wolstenholme, A. J., I. Fairweather, R. Prichard, G. von Samson-Himmelstjerna and N. C.

904 Sangster, 2004 Drug resistance in veterinary helminths. Trends Parasitol. 20: 469-476.

905 Yu, L., L. P. Castillo, S. Mnaimneh, T. R. Hughes and G. W. Brown, 2006 A survey of essential gene

906 function in the yeast cell division cycle. Mol. Biol. Cell 17: 4736-4747.

907 Zhang, M., C. Wang, T. D. Otto, J. Oberstaller, X. Liao et al., 2018 Uncovering the essential genes

908 of the human malaria parasite Plasmodium falciparum by saturation mutagenesis.

909 Science 360: eaap7847.

910 Zhu, G., G. Salazar, S. A. Zlatic, B. Fiza, M. M. Doucette et al., 2009 SPE-39 family proteins interact

911 with the HOPS complex and function in lysosomal delivery. Mol. Biol. Cell 20: 1223-1240.

912 Zuryn, S., S. Le Gras, K. Jamet and S. Jarriault, 2010 A strategy for direct mapping and

913 identification of mutations by whole-genome sequencing. Genetics 186: 427-430. 
bioRxiv preprint doi: https://doi org/10.1101/2021.06.16.448744 this version posted June 19,2021 . The copyright holder for this preprint (which was not certified by peer review) is the author/funder, who has granted bioRxiv a license to display the preprint in perpetuity. It is made available under aCC-BY 4.0 International license.

\section{Figure 1.}

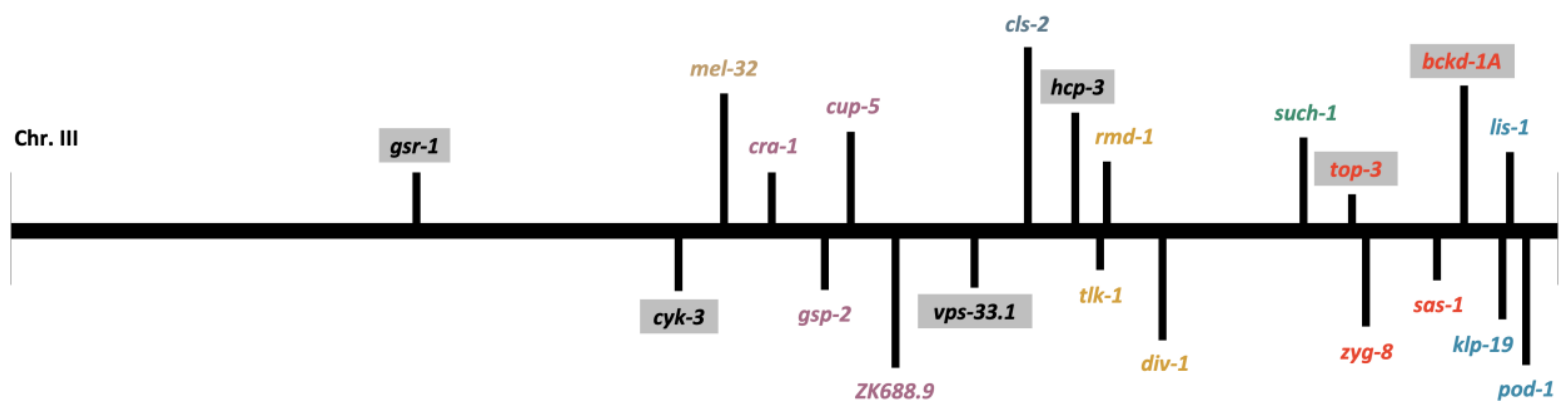

sDf125

$\mathrm{nDf} 40$

sDf110

nDf16

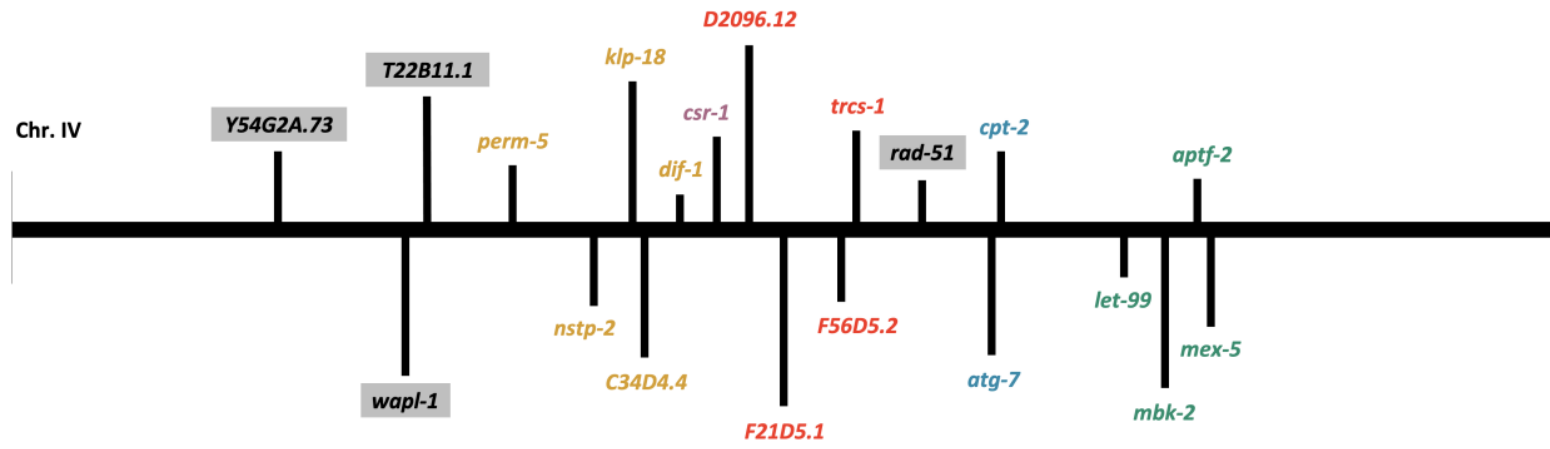

nDf41 sDf21

eDf19

stDf7

sDf2

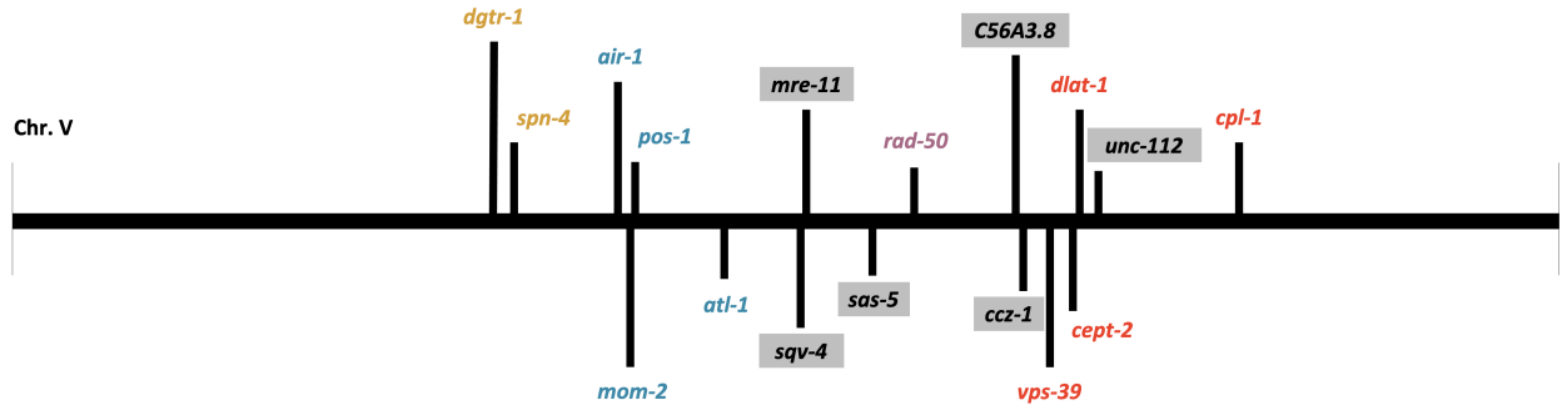


bioRxiv preprint doi: https://doi.org/10.1101/2021.06.16.448744; this version posted June 19,2021. The copyright holder for this preprint (which was not certified by peer review) is the author/funder, who has granted bioRxiv a license to display the preprint in perpetuity. It is made available under aCC-BY 4.0 International license.

\section{Figure 2}

918

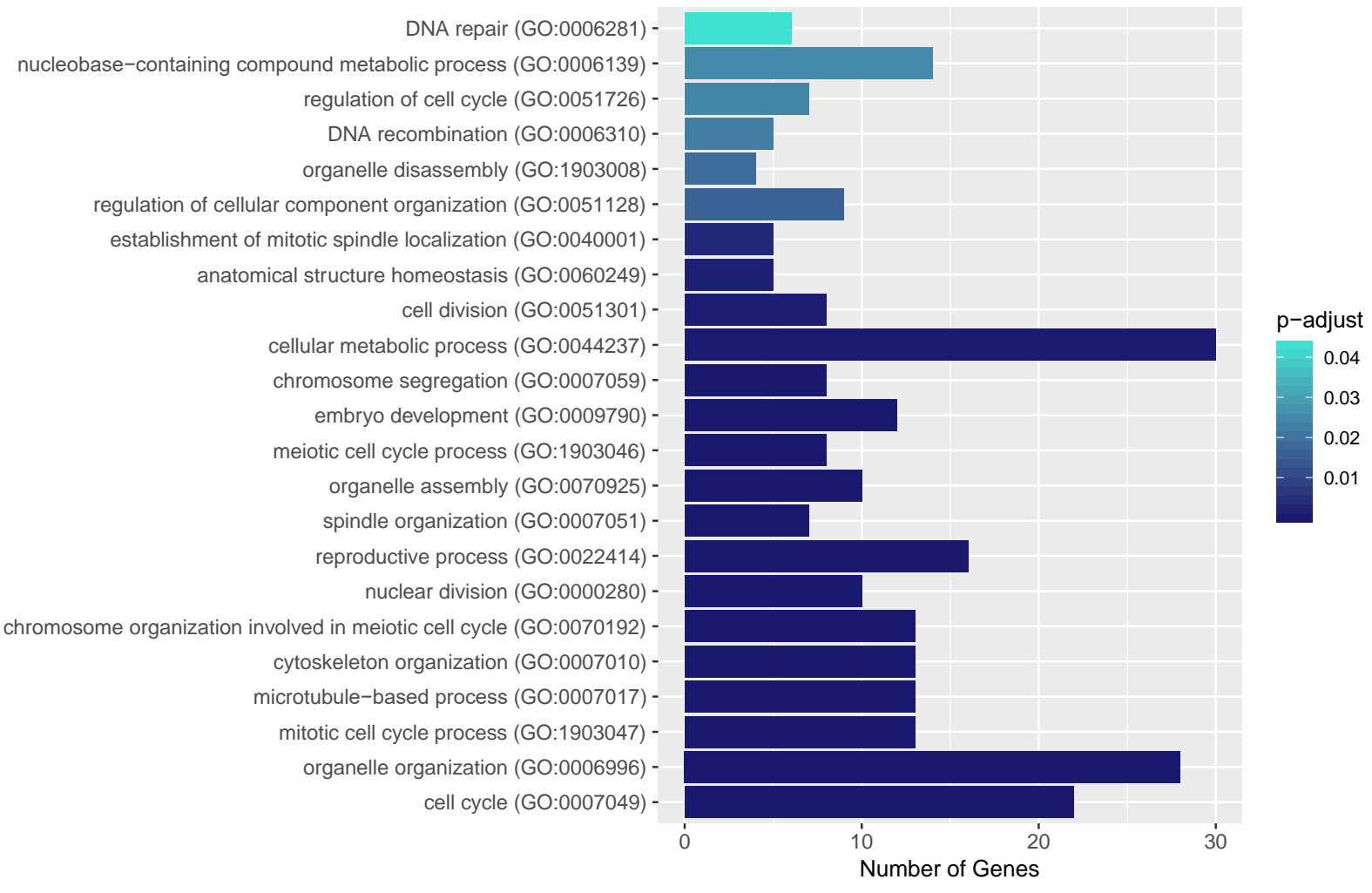


bioRxiv preprint doi: https://doi.org/10.1101/2021.06.16.448744; this version posted June 19, 2021. The copyright holder for this preprint (which was not certified by peer review) is the author/funder, who has granted bioRxiv a license to display the preprint in perpetuity. It is made available under aCC-BY 4.0 International license.

\section{Figure 3.}

\section{3}
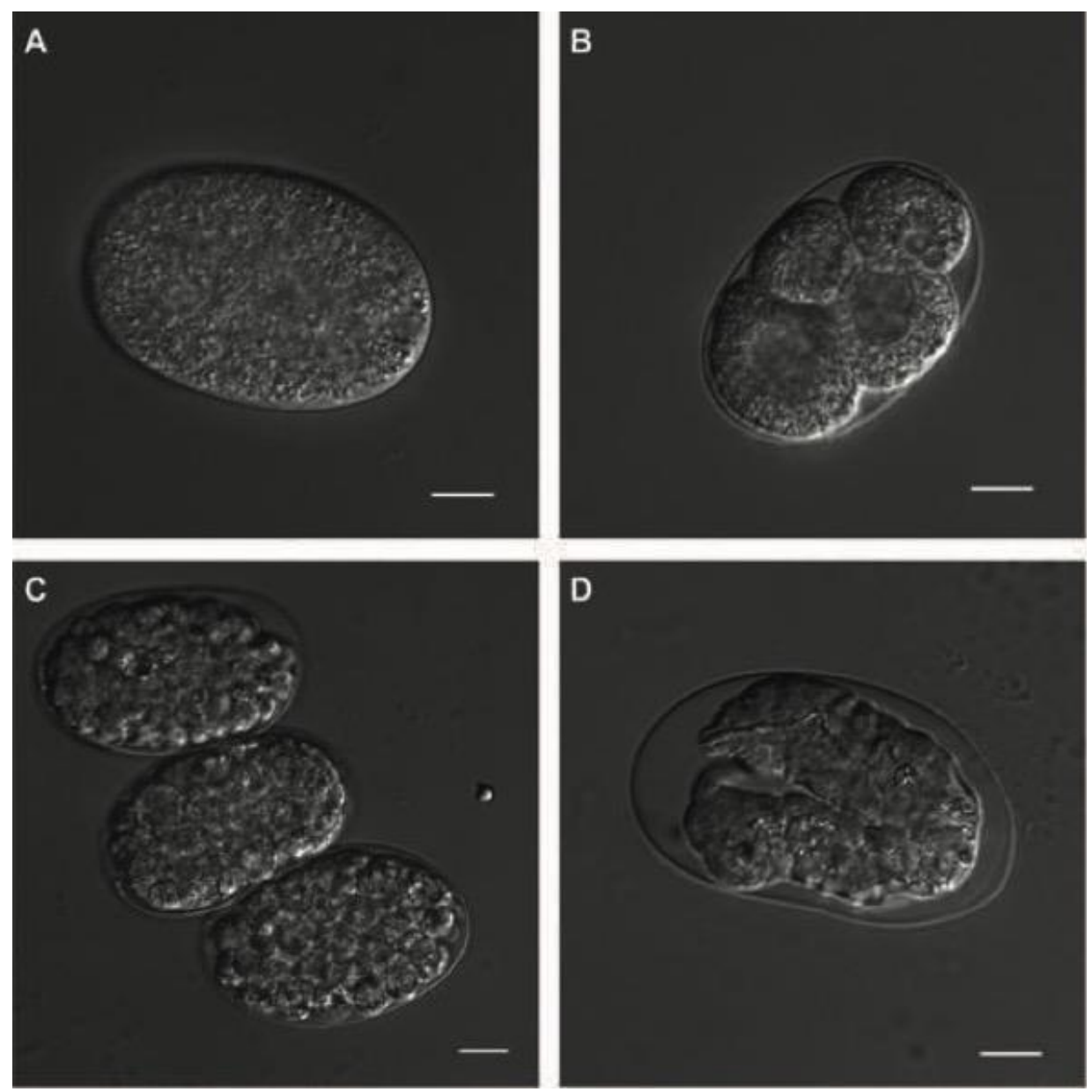